Historic, Archive Document

Do not assume content reflects current scientific knowledge, policies, or practices. 
. 
62.13

MOHICAN

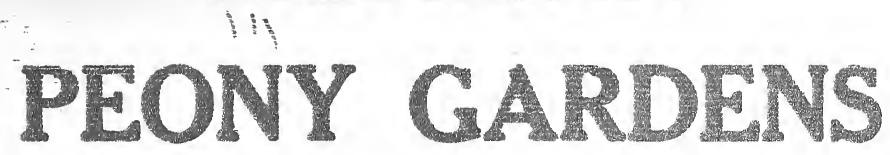

SINKING SPRING

PENNSYLVANIA

$\frac{\text { AUGUST }}{1916}$ 


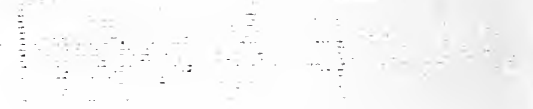


THE QUEEN OF FLOWERS-THE FLOWER FOR THE MILLION AND THE MILLIONAIRE

\section{AUGUST, 1916}

SPECIAL NOTE-We issue this Peony catalog annually in August, and it is always brought up to date. If there are no striking changes in the text, it means simply, that there is nothing new to be said. Prices, however, invariably undergo some change each succeeding year. Quotations therefore in this catalog supersede those in all former editions. Obviously also those whom this catalog reaches after the present fall shipping season is over, should not order for the fall of next year until the 1917 edition reaches them next August.

\section{s}

\section{$M$ o h i c a n P e o n y G a r d e n s SINKING SPRING \\ PEN N S Y L A N I A}

WM. W. KLINE

J. R. HUFFORD 
6 HERE are supposed to be over $(1$ two thousand varieties of Peonies, and, unfortunately,-more coming. They are NOT all good. In form, some are inartistic freaks-tho highly lauded. Other's are utterly impossible in color. Hundreds, tho masquerading under different seductive titles at high prices, are identical. Our mission for years has been to sort and sift, and to-day by reason of this process of elimination, we offer only the choicest and best, and the most distinct of the many hundred varieties in cultivation. This relieves you of the perplexing problem of selecting from confusing and endless lists of varieties. We are thus specialists in the truest sense; which means not merely the offering of the best sorts, and ONLY the best; but includes the guarantee that every root we send out is true to name, and the stock highgrade, liberally grown "qualitystock," offered at the lowest consistent prices. 


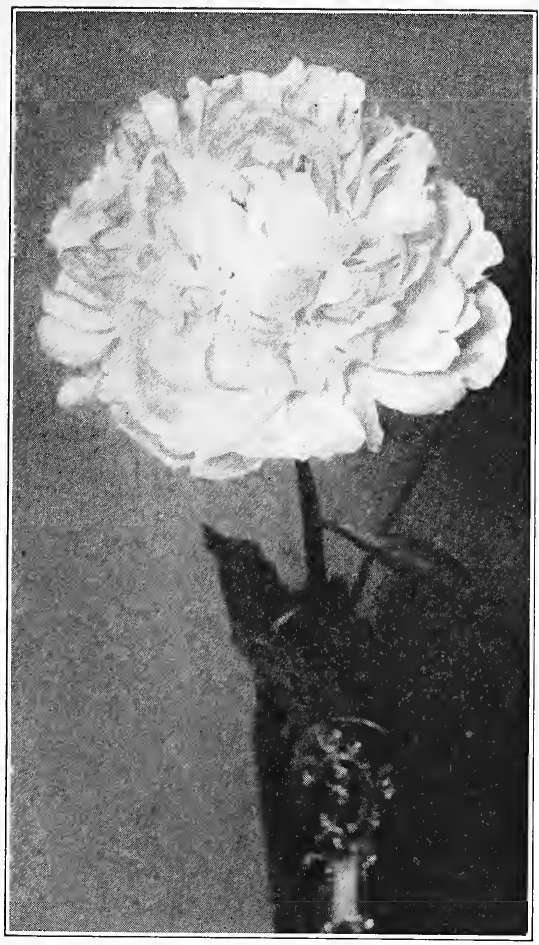

\section{Foreword}

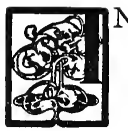

this the eleventh annual edition of our catalog, we present some new illustrations from photographs of our own flowers, and as usual, some necessary alterations appear in the schedule of prices; but for the most part, we continue the general text of our recent former editions with but few changes and these of little practical consequence. For there is really nothing new to be said, and we see no reason to alter in any way the observations and arguments already made.

But we again renew not alone our thanks to our many friends for their valued patronage from year to year, but also our sincere appreciation of the very many letters we have received in which the writers have set forth-often at some length-a confidence in us, and an approval of our policy and our methods of doing business. These kind expressions have been very gratifying indeed, and serve not only as an incentive to renewed effort, on our part, in the one right direction, but to supply abundant proof that our early estimate of a plan that would bring to us the patronage of the great majority of discriminating Peony buyers was a correct one. This is amply proved by the extraordinary volume of business that has come to us in recent years, - an annual increase decidedly beyond the normal; in short our success has been such that we have been scarcely able to keep pace with the demand for our Peonies.

We believe that the majority of our patrons have pretty well made up their minds about the Peony situation,-and about us,-but for the benefit of those who receive our book for the first time this fall it may not be amiss to inquire briefly into what "specializing" really is. Apparently there are specialists and specialists, and we have our own version of what a Peony specialist is, or should be.

The term "specialist" is often an empty catch word and indicates, really,-nothing in particular. We believe that true specializing means the devotion to, or study of, one single thing, in any line of effort. We believe that true Peony specialists should not only supply high-grade and 
perfectly grown stock true to name, but that there should be also a constant effort towards elimination-the throwing out of all worthless and duplicate kinds. To present a list of more than one hundred sorts, at the most, shows, it seems to us, a disability to intelligently eliminate.

We are growing Peonies and nothing else. This one flower has our undivided personal time and attention, devotion and study, and we are by the way the only extensive growers of Peonies exclusively in America. We also take pride in the fact that we have fewer varieties and at the same time a larger stock, than any other "specialist" grower we know of. Added to this, we have an intimate personal acquaintance with every plant of the many thousands growing in our fields, and thus we are able to guarantee every root we send out to be absolutely true to the name under which it has become identified. When you order Festiva Maxima or Eugene Verdier from us, we send what you pay for, not something more or less like it under the name.

We invite you to come and see our fields, not merely at blooming time, but during the summer, so that you may see something of the extreme care in our system of cultivation, which together with our ideal soil enables us to produce a root unexcelled, perhaps unmatched, for health, vigor and rapid growth. Our plants are grown wide apart, yet no rough horse-cultivation is employed. Men with hand-hoes are constantly in the fields and the ground is always kept loose and mellow. A visitor recently said in something like amazement upon viewing our fields: "Why, I never saw anything like this! There's not one weed, not even a stray blade of grass to be seen anywhere. It reminds me of one of those ludicrously perfect pictures of a garden in a seedman's catalog."

As a matter of fact, we think it no exaggeration to say, that we believe every individual plant growing in our fields, receives more careful and better culture than it gets in the average amateur's garden-after it leaves our hands.

We have discontinued offering at special prices the "clumps" we accumulate, preferring to let them go out in filling regular orders from time to time. Nor do we list so-called one-, two-, and three-year roots, because as we point out in the body of this book these terms indicate nothing definite at all, and a customer has no knowledge of what he may expect to receive.

We send out only established plants; that is to say, we grow and "coach" our roots, if we may so express it, until they reach a certain stage at which we deem them fit to send to a patron who wants a display of flowers the following spring. Some of the roots we ship are three and even four years old, depending upon the variety. And when shipping time arrives we personally stand over every root dug, labeled, packed, and shipped. 
This then is why we call ourselves Peony specialists. But it is what you think that counts, and we feel that the most significant thing we can add to the above argument is to direct your attention to the letters printed on the last few pages of this catalog. We have never solicited a single testimonial; and every letter of appreciation which has ever come to us has been entirely voluntary on the part of the writer. We think we are justified in saying that stronger expressions of favorable testimony to superior merit of goods, have never been received by any firm in any line of business, than those which have come to us in recent years.

These letters amply demonstrate the correctuess of some theories we have held from the beginning; namely, that people wanting to purchase a few Peonies-or many-and wanting the very best obtainable, were about sick and tired of thumbing over pages upon pages, in catalogs, containing endless list of varieties; that they were beginning also to seriously doubt the genuineness of many sorts listed-doubting the real difference of most of them, except in name; that the statement that there are no poor Peonies is not true; and that true specializing should not be defined as a raking together of all the worthless sorts produced in this country and abroad.

Consequently after ten years of experimenting with many varieties of Peonies before offering a single root for sale (and this period was prior to the advent of any of the present-day Pcony Spccialists) we issued our first annual catalog eleven years ago and adopted this fixed policy-three-fold in character:

First_-To supply our patrons with the choicest and best Peonies (and ONLY the choicest and best) that have yet been introduced.

Second-Not to befool our patrons with new varieties of indifferent quality at high prices.

Third-Not to figure upon how small a root we might venture to send for the money; but how large a one we could supply at a fair margin of profit to ourselves.

We feel that we have adhered pretty closely to the above, which fact will serve perhaps to sufficiently explain the phenomenal growth of our business.

As a matter of fact our success has been such that as before stated we have found it difficult to keep pace with the demand for our Peonies. It may not be out of place to set down the rather extraordinary fact that during a period of several successive years, our business was doubled, and doubled again, and the annual increase since then has been decidedly beyond the normal. An analysis of the figures also reveals the gratifying fact that an unusually large proportion of our annual sales are made to former patrons or to those whom our patrons have told about us.

All of which, it seems to us, is strikingly significant-evidence merely of the little "revolution" we are engineering-a revolution in method,- - a little more fairness and liberality than has commonly been in vogue amongst nurserymen generally and even other Peony "specialists." 
In the matter of varieties we believe we are keeping fully abreast of the times. We are always carefully observing and testing new sorts, and this year we make a few changes in our list of ONE HUNDRED BEST VARIETIES. Many new (?) varieties continue to flow-as they ever will-both in this country and abroad, all of which tends to still further confuse the situation and advance the cause of the general mix-up in I'eony nomenclature.

We cannot refrain from stating that the annual introduction of new sorts at very high prices-often from five to fifteen, and even twenty-five dollars being asked for a root--is simply a beautiful money-making scheme, and many people have been sadly disappointed in these "exquisitely beantiful new and rare varieties." As a matter of fact-much as we regret to say it-ninety-five per cent. of these "new and rare sorts" are framds, pure and simple, and for one or more of these three reasons: First, the Peony does not surpass, and often does not begin to equal, other existing sorts that can be had at from fifty cents to a dollar and a half; Second, it may not be distinguishable, by anyone except an expert from other sorts to be had at perhaps one-tenth the price; Third, it mal be just a poor Peony - nothing more-and should nerer have been introdnced at any price. We decline to take part in this particular game, and it is an astonishing thing to us that any grower should engage in it. There are, just now, about eighteen or twenty Peonies of this sort being offered at prices ranging from \$6.00 to \$25.00. Most of them are extravagantly lauded whites. We see no reason to list them at amy price. In every case they are either practically identical with-or else inferior to such varieties as Avalanche, Baroness Schroeder, Grandiflora Nivea I'lena, Aurora, and siolfatare.

The real truth of the situation is just this: (and we have no hesitation in going on record with the statement, which we admit is extrardinarily strong) It would seem that the limit of perfection in Peonies has not only long since been reached, but the range of colors, combination of colors, sharles, - tints, we now have, is so varied, that it is impossible to add anything really different-that is, any new I'eony sufficiently distinct to warrant its introduction. Any known Pcony, quoted elscuhere, and not on our list, is ABSENT FOR CAUSE.

Considering the stock we supply, both as to quality and trueness, our schedule of prices remain as low as-or lower than-that of any other responsible firm or grower. Certain varieties, than which there are scarcely any choicer sorts in cultivation, have been offered in certain quarters as low as 50 cents, and even 25 cents. Obviously such prices on these varieties are not "possible," and we get a good many letters from time to time from people expressing chagrin at having been lured by them.

We advertise invariably only in the fall issues of the magazines, and at your request it affords us much pleasure to send you this catalog. We have little faith in the efficacy, or wisdom of the so-called "follow-up" system. We shall therefore not annoy you from time to time with post-cards and the like, further importuning you to buy. This, our annual booklet, is our one and only effort of the year to induce you to become one of our patrons.

Very respectfully yours,

WM. W. KLINE,

August '1, 1916.

J. R. HUFFORD. 


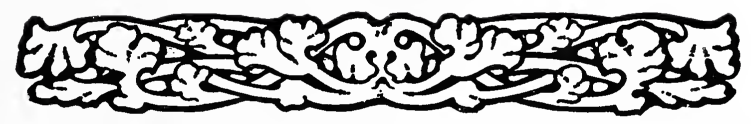

\section{An Inspiration, - On Viewing Our Peonies BY A VISITOR}

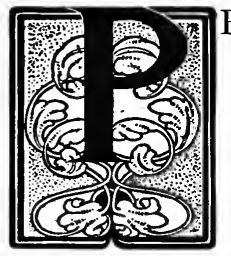

\section{EONY!}

Fairest flower, Rarest flower!

Not the poppy's brazen splendor,

Not the rose's thorny coyness,

Not the languor of magnolia,

Nor the mignonette's allurement,-

Tho in each a charm there lingers,-

Can approach thy full perfection,

For thou joinest all their graces,

Blending them in thine own beauty,

Gossamer texture,

Lustrous, gleaming,-

Fragrance richly sweet and spicy,

But with subtle tang and flavor,

Satisfying, never cloying,- -

Secrets, these, of thine enchantment.

Scorning shyness as unworthy,

Lifting proud head without boldness,

Simple, chaste, and unpretending,

Standing straight, strong, self-reliant,

Pure without a thought of coldness,

Regal in thy stately glory,

Delicate withal, and soulful,-

Thou canst bear a message holy,

Carry passion's throbbing whisper,

Grace the festal ceremony,

Each with equal charm and fitness.

Glorious flower,

Flora's choice from her own bower,

Queen thou art without a peer!

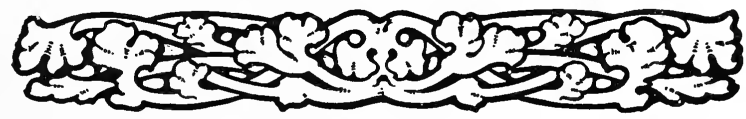

Copyright 1910, by William W. Kline. 


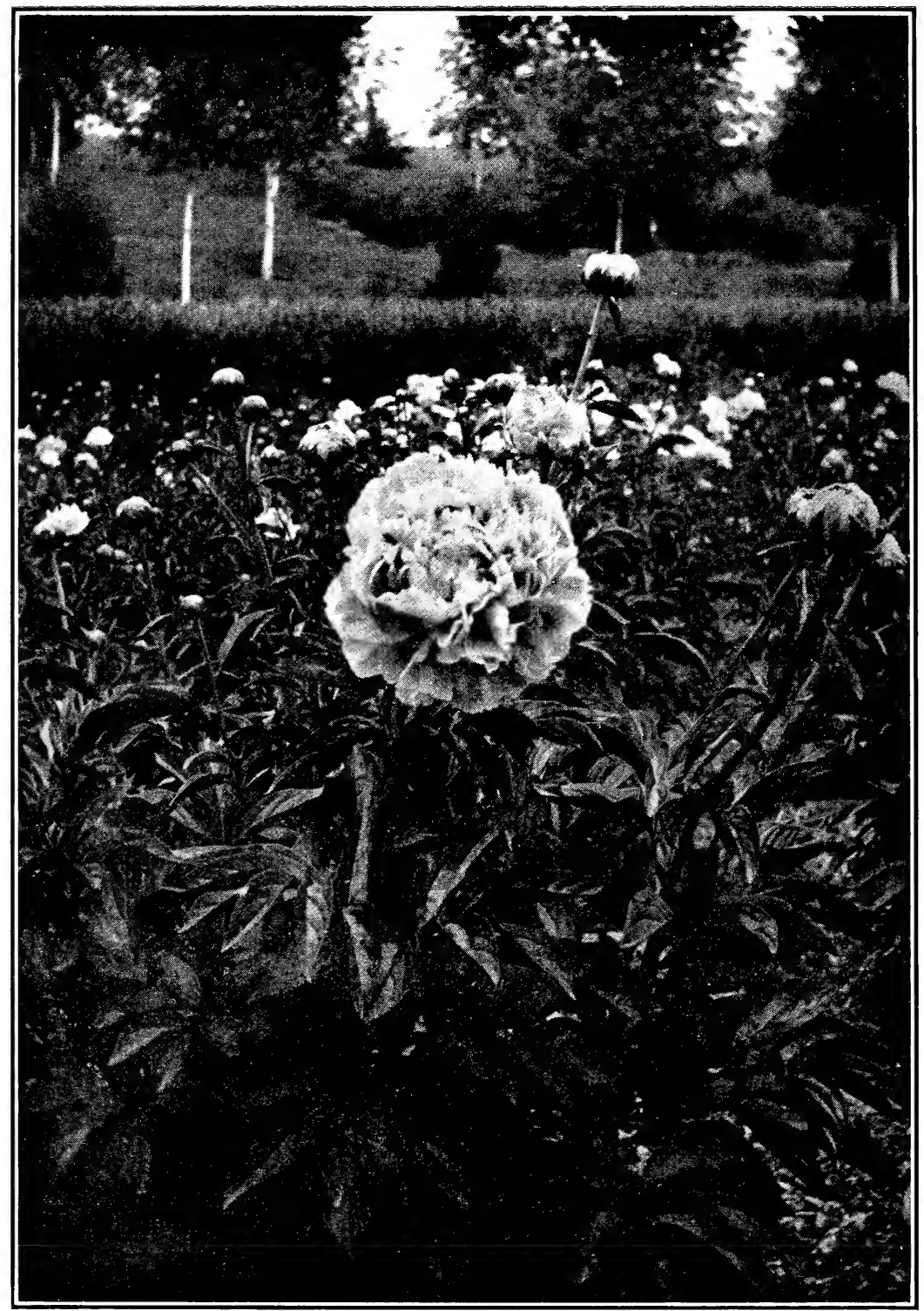

OUR EXHIBITION GARDEN, WITH "ALBERT CROUSSE” IN THE FOREGROUND 


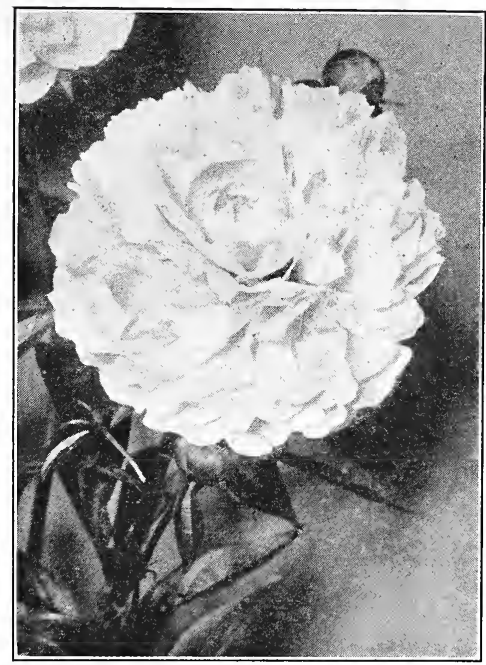

\section{THE MODERN \\ DOUBLE HERBACEOUS}

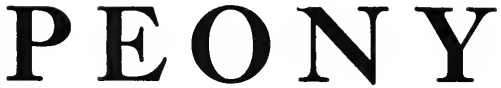

(Pœonia Herbacea Sinensis)

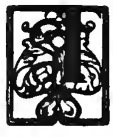

HE PEONY is crowned Queen of the whole realm of Flora. Allowing for due prejudice and enthusiasm on our part, it sems to us that this fact is beyond question or dispute. When we first ventured the assertion years ago in our annual cata$\log$, we confess to some trepidation in doing so, lest in our zeal we should be taken to account by somebody, and be named either mad, or heretics, for daring to call the Peony "Queen of Flowers" over the Rose. But in a very few years the modern improved Peony has made such remarkable strides in public favor, and its truly regal magnificence is so much better understood and realized by the general public, that we believe today there are thousands of people who will agree with us when we say that there is no flower so well deserves the title of Queen.

It seems but yesterday that Peony enthusiasts, tho a merry little band, were few in numbers; but they were patient and they were wise, for they knew of the long years of patient labor of those men devoted to hybridizing and intercrossing, and the marvels that had been-and were being-wrought in Peony improvement, and that this flower would one day, in all its wealth of perfect loveliness, take its place as the Queen of Flowers. That time has now arrived, and while there are a few people here and there who have not yet been brought to the realization (because they have perhaps never seen the improved Peony), that the day of the old red "Piney" of childhood days is past, who that has looked upon the best of the glorious modern blooms will honestly compare them unfavorably to the loveliest Rose that ever bloomed in a professional's greenhouse?

In view, therefore, of the now generally and well understood merits of the Peony as it is today, we think that to attempt oratorical flights by way of eulogy would be superfiuous in this edition of our annual catalog. We think it rather more necessary-as will appear further on-to call your attention to some details about the business end of the Peony-matters of vital importance to purchasers-which have long needed some expounding. 


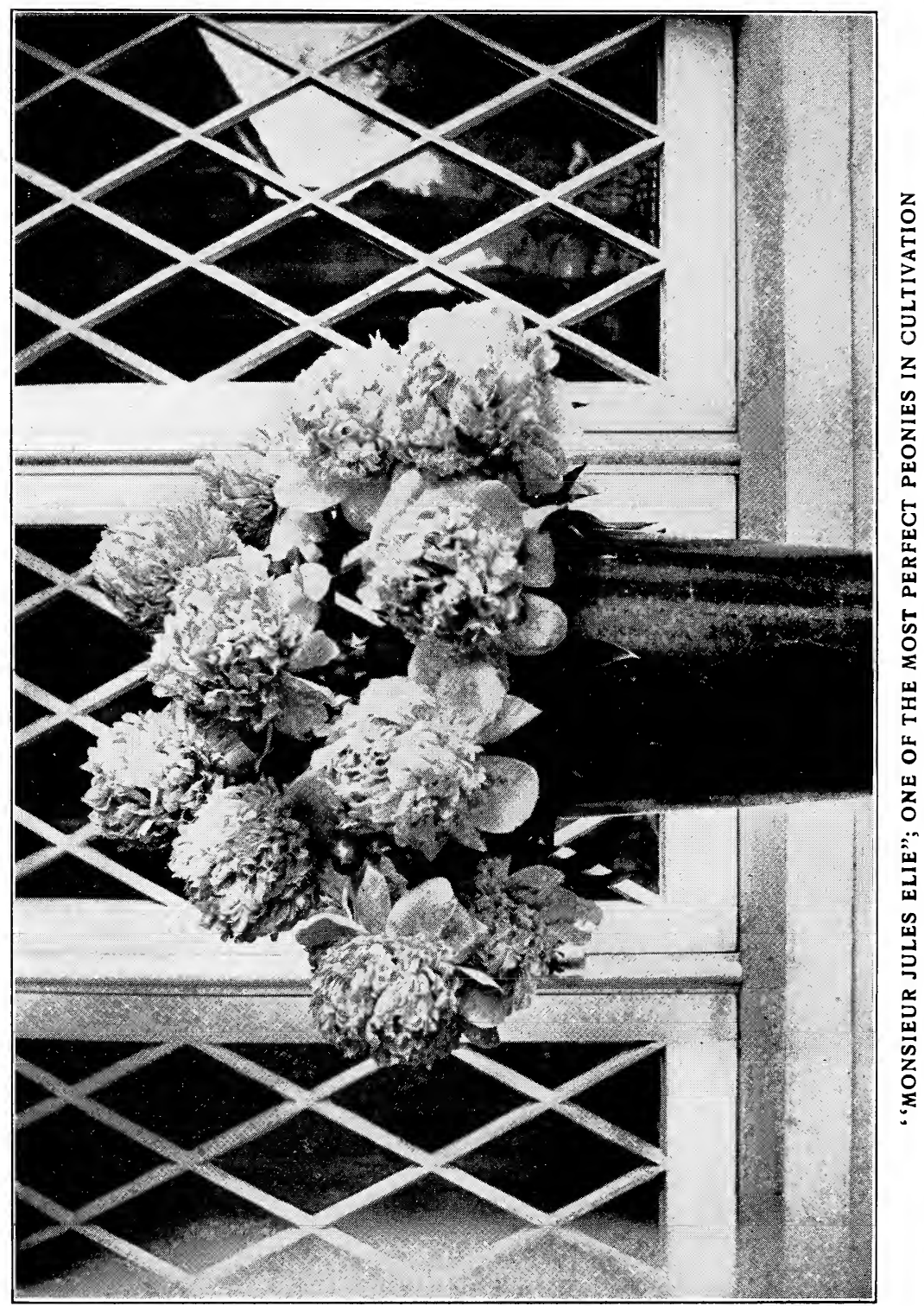


PROMINENT British grower of Peonies has well said that "the Peony is the flower for the million and the millionaire." By this he probably meant that there is no flower that serves so well or is so extensively employed for glorious and imposing effects on the grounds and estates of the wealthy class, and at the same time is so well adapted to the modest garden where no attendant is employed and where the hours spent by the owner in his or her garden are limited. For the Peony is independent and vigorous, and takes care of itself.

Once planted, all is done; nothing more is required beyond perhaps a liberal dressing of bone-meal every fall, and each succeeding year adds to the size and beauty of the flowers. Consider these features: The Peony is as hardy as the oak-singularly free from diseases as well as insect pests of any sort. No dusting, spraying or hand-picking of worms. No roots to take up each fall, as with the dahlia. The foliage is rich and glossy and of a beautiful deep green color, thus rendering the plants very ornamental even when out of flower. All of the improved varieties are deliciously sweet-scented, and many surpass the rose and carnation in delicacy of fragrance. The flowers are of immense proportions, reaching in some instances the large size of seven to nine inches in diameter and five to six inches in depth. The range of color, too, is so varied that almost every tint of pink, red, and crimson is comprised in the list. Many of the varieties are as chaste, delicate and refined as the daintiest rose.

Now there are upwards of two thousand varieties of Peonies, and it is a fact-which no grower or nurseryman can honestly dispute-that hundreds of them are so nearly alike as to be practically identical. In any event, only an expert can distinguish the difference. If you send to certain worthy growers for a catalog or list you will be confronted with more or less accurate descriptions of perhaps from two to five hundred sorts. The average retail customer is confused and perplexed by this array. He wants a few of the very best-the newest and most desirable; perhaps a half dozen or a dozen and perhaps not even that many kinds, to plant either singly amongst his shrubs or to arrange in beds. He doesn't know which to choose. Each description in the big catalog seems to outdo the one just gone before. He plods on for awhile, then finally goes back to the head of the list and starts afresh.

At last, in desperation, he makes a selection, and he is quite as likely to get the poorest as the best. And we may add that we cannot agree with the expressed opinion that "there are no poor ones." There are! Some well-advertised varieties are poor in form; others last no time at all, even if cut in the bud and placed in water. Some of the tricolored varieties are distressing combinations of color. We have in mind in particular one extensively boomed tricolor that can scarcely be said to sustain its reputation for beauty. 


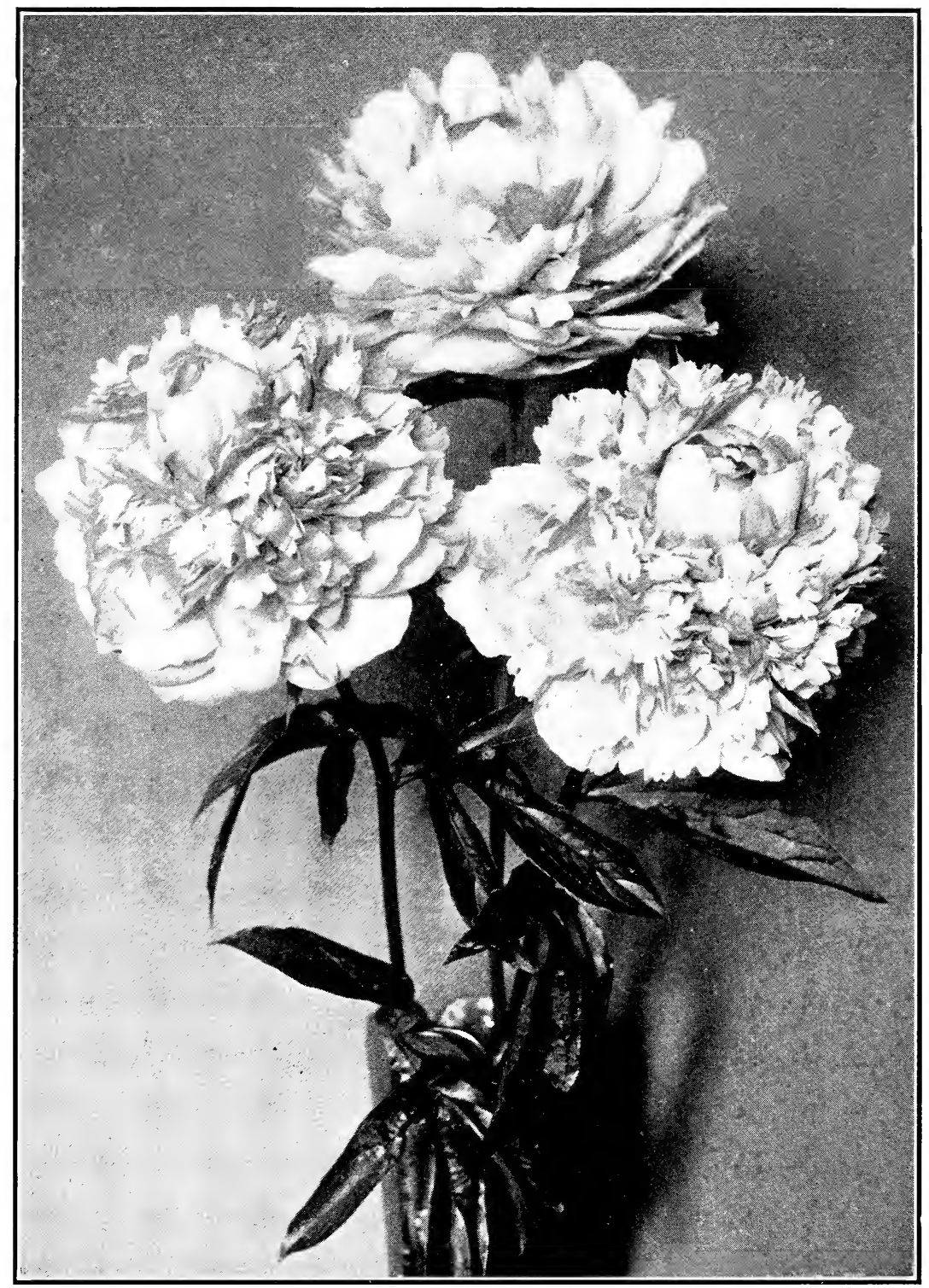

"M A D A M G E I S S L E R"

Enormous, massive, globular bloom; a marvelous flower, always creating a sensation. Ranks with the very best. 


\section{Our Lis t}

Our list now consists of exactly one hundred carefully selected sorts of Double Herbaceous Peonies. Frankly this number of varieties is far in excess of the number that really should be offered to the general retail trade, unfamiliar as it is with Peony nomenclature and the many distinctions-often without a difference. Every grower, if he wanted to be honest about it, would confirm this statement. But, all within the past few years, there has come into existence a steadily increasing number of Peony cranks; and we use this term in a complimentary sense, if we may so express it, certainly without disrespect, for we are members of the order ourselves. These customers demand the new and "rare" varieties, and they will have them, whether or not these new sorts actually surpass the older standard kinds.

We are, and have been, growing for years several hundred varieties. The number and character of the varieties in our fields has been constantly changing and shifting, as we have cast some out as not entirely worthy and tried the new ones as they came into general cultivation. Our list of one hundred sorts as now made up we consider absolutely complete and beyond the advisability of a change in a very long while. We deem them the CHOICEST AND BEST AND THE MOST DISTINCT OF THE MANY HUNDRED VARIETIES IN CULTIVATION. The points constantly kept in mind in making the selection have been size, perfection of form, fragrance, vigor of bloom, lasting quality for cut flowers, and landscape effect. The entire range of form and color is covered absolutely, and all of the exquisite and really worthy new things of French and British production have been added. If you do not find listed in this booklet a variety you think ought to be here, it is because a better one has displaced it, or, for the reason that it is practically identical with one listed. For example: there is "Albatre." We do not list it because it is absolutely identical with our "Avalanche." Likewise, (as an instance in the case of the lower priced sorts) we do not offer "Delicatissima," because we have been unable to observe any marked difference between it and "Floral Treasure." We may add here that we do not offer Tree Peonies, Peonies of the Officinalis section, nor the single varieties. The first named is very hard to manage, slow of growth, and does not fully mature under ten years. The Officinalis sorts are also slow to increase and for several reasons are undesirable; while the single Peonies are in slight demand and rather unsatisfactory.

\section{"Rare" and "Fine"}

Judging from the contents of some letters we have received, a great many people are misled by the descriptions attached to the varieties in 


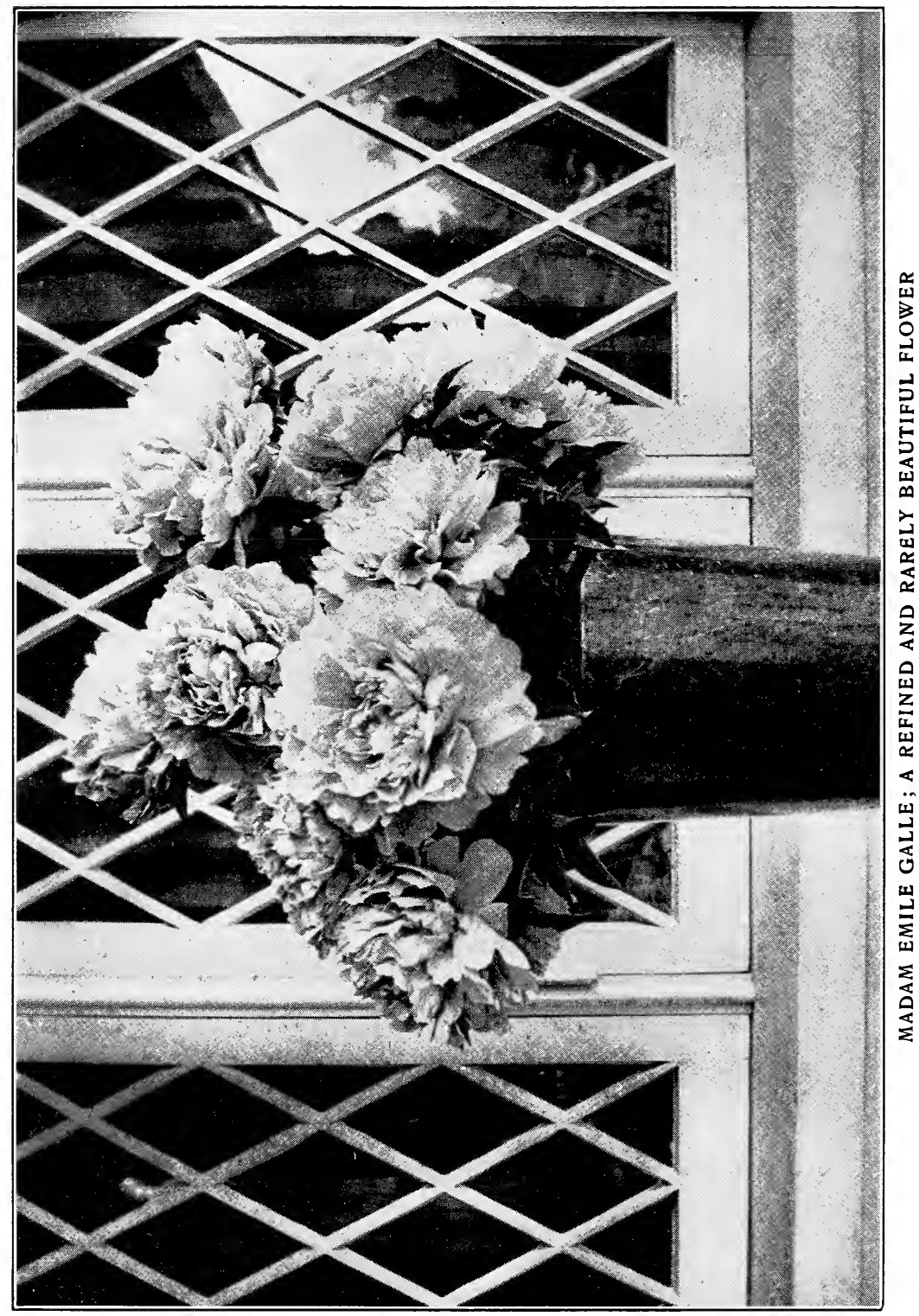


many catalogs, including our own. It is perhaps natural that in these cases persons should fancy the word "rare" to mean "very fine"; especially when an exceptionally high price is asked for the variety. In point of fact "rare" and "fine" are not always synonymous in these instances, and for the benefit of intending purchasers we desire to say that in this booklet and its accompanying price lists, many varieties quoted at $\$ 3.00$ and upwards do not surpass-sometimes do not equal-other sorts at considerably lower prices. The very new sorts of recent introduction that some people insist upon having because they are new, are "rare" and highpriced because there is as yet no considerable stock of it in existence. It does not necessarily mean that they surpass the somewhat older kinds.

\section{P l a n t ing}

The Peony is of such easy culture that there is little to be said by way of introduction as to planting, altho we send out a little book of instructions with every order. It is scarcely necessary to say, that Peonies respond nobly to liberal culture. Prepare your ground well, therefore, by working up deep, rich soil with a good quantity of bonemeal incorporated and you will be well repaid by the increased size of fancy blooms and the general vigor of the plants. It is best to avoid the use of all animal fertilizer. The root should be set in the ground with the topmost "eyes" about three inches below the surface of the soil, and the ground well firmed around it-using care not to damage the tender buds. For permanent planting Peonies should be set from three to four feet apart each way, and left undisturbed indefinitely. When it is desired to intersperse Peonies among other hardy garden flowers, or at intervals along a border of shrubs, they should be planted in groups of from three to five, each group to be of one variety. In arranging a bed of Peonies of from fifteen to fifty roots-according to the space at command-we strongly urge the planting of one variety. For while sorts may be had that bloom in theory about the same time, the result is never satisfactory, for in fact they come straggling into bloom one after the other and the effect desired is never wholly gained. A bed of one fine sort is a magnificent sight.

\section{Time to Plant-Not in the Spring Season}

It is a pity-for the sake of the Peony-that when the fall sets in the great majority of people forget about flowers and their gardens and turn to other things, for the fall season is the only season in which the Peony should be moved. We have discontinued spring shipments and supply roots only in the fall. To move Peonies at any other season than the months of September and October means a set-back from which the 


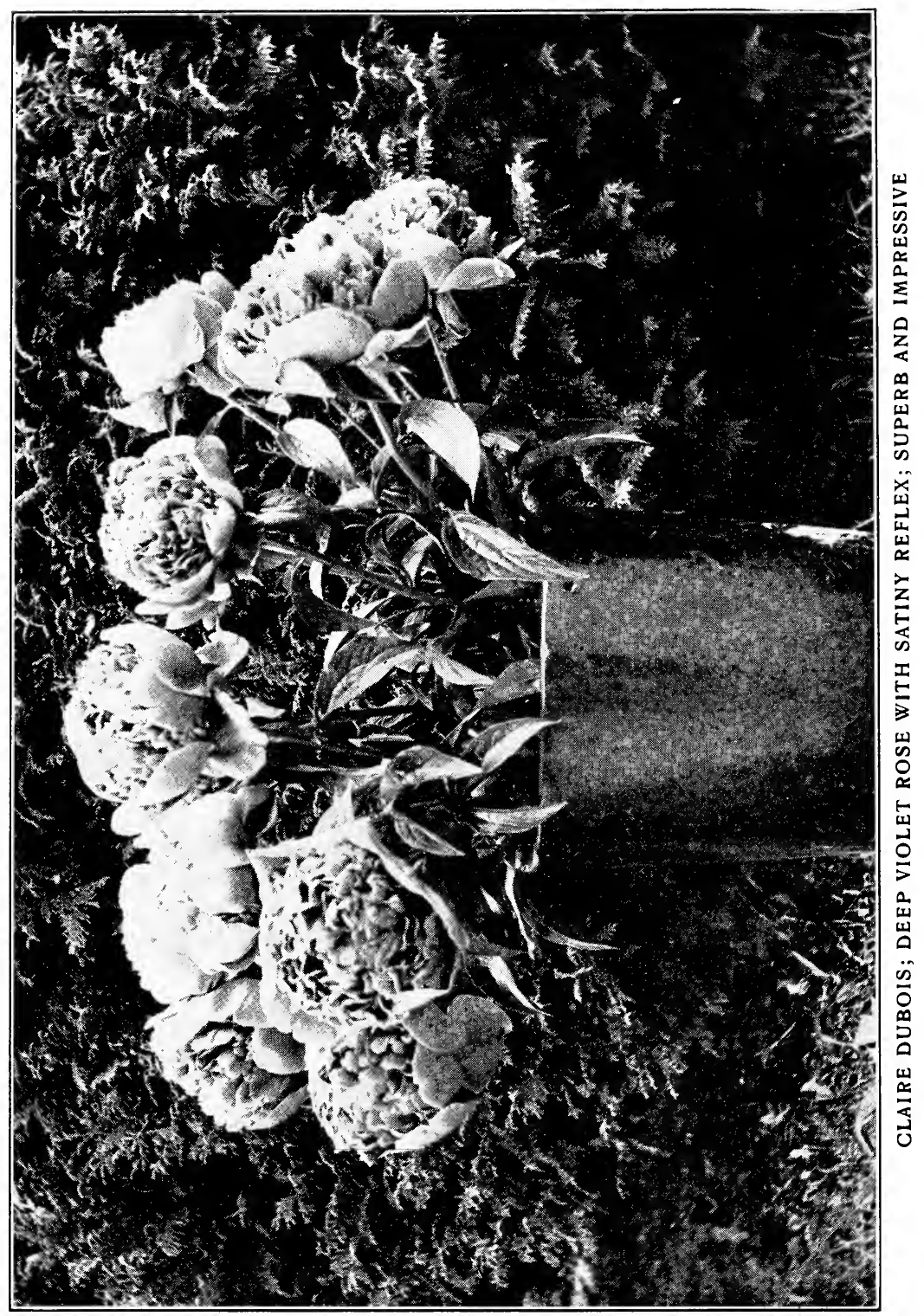


roots sometimes do not recover for two years. Most general nurserymen will supply Peonies at nearly any season of the year that they can be gotten out of the ground. But we are building up a reputation for fair dealing; that is to say, when we sell you Peonies we want them to start right in to "work" for you from the beginning, without a set-back through moving at the wrong season. We have faith that our methods will thus redound to our credit.

Carefully observant growers agree generally that, under normal conditions, the best time for moving Peonies is during the month of September and early October, since it is essential that some root-growth be obtained after moving and before freezing weather sets in. Buds for the following season's bloom are usually fully ripened by the last week in August; the foliage still being green at this period being no indication whatever to the contrary. We begin digging on September 1st and no orders are filled later than November 1st. This is for your sake-not ours.

While our system of growing is such that we are able to fill the last order received with the same grade of stock with which we fill the very first one in, yet it is a help to us--for several reasons-to have all orders in early. We ask, therefore, that customers send in their lists as soon after the receipt of this catalog as convenient.

\section{Purchase Your Peonies from TRUE Peony Specialists}

In these days pratically every one offering Peonies calls himself a "Peony Specialist." Those who grow "other things" besides Peonieseven the general nurserymen-are "Peony Specialists." The phrase is easy. But with us the Peony is the "whole thing." It has our undivided time and attention, devotion and study. We grow Peonies and nothing else. We are thus specialists in a sense which possesses a legitimate value and significance, and the reasonableness of our suggestion, that you purchase your roots from TRUE specialists, becomes apparent. We have no slighting words to say about the many reliable firms of general nurserymen; but it seems a rational conclusion that concentration of effort - specializing-by an individual or firm, upon any one branch of horticulture, would be productive of the best results for intending purchasers. The argument applies in every field of human effort. It is especially applicable in Peony culture, for it may be said without reservation that Peony nomenclature is in the utmost confusion. Many listed varieties are spurious, and new and weird names are coined every season and applied to old varieties. The most charitable interpretation to be put upon this proceeding is, that it is done because the growers have lost track of things in their fields, and not because they want to lead the public to be- 


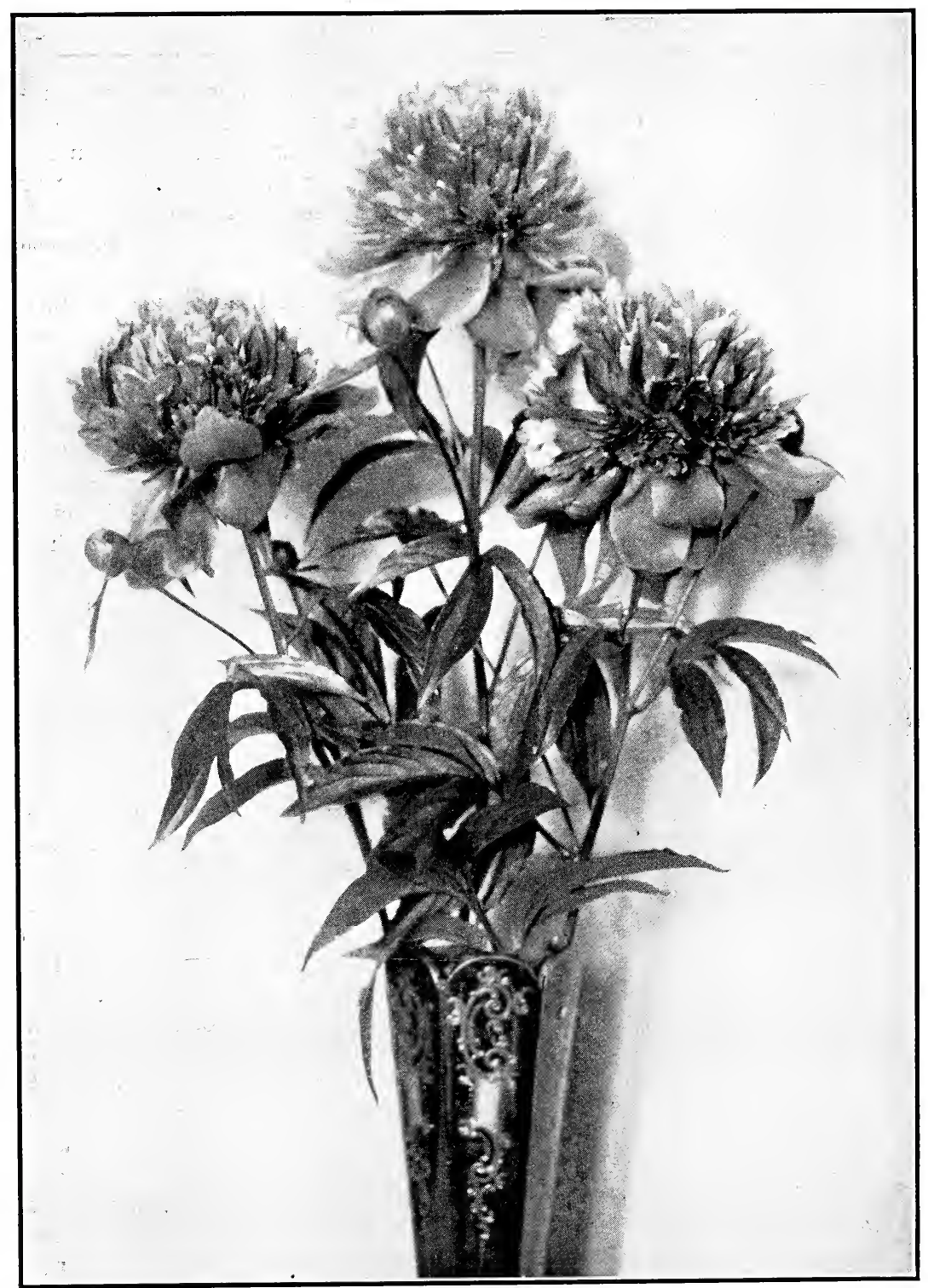

"SOUVENIR DE LA EXPOSITION DE BORDEAUX"

An imposing wonderful flower; bluish violet or wine color; very distinct. Nothing else just like it. 
lieve they are offering new varieties. Many of the varieties we offer are difficult to obtain true in any quantity, and much of our original stock of certain sorts was secured at very high prices, which we were willing to pay because we knew the stock to be correct. Even such well-known and distinct varieties as Festiva Maxima, Couronne d'Or, etc., are often spurious as received from supposedly responsible growers, and, as we indicate elsewhere, three inferior Peonies are being sent out in place of Eugene Verdier.

We have labored and studied, and spent a great deal of money to get our varieties true. We so guarantee them, and we stand ready and willing to replace any that prove (after they have reached their normal blooming period) to be otherwise.

\section{Size of Roots-“Divisions"-"Small"-"Medium"- "One Year," Etc.-Confusion of Terms- Important, Read Carefully}

The rapidly growing interest in the modern Peony-a popular interest which has attained such proportions that it is not out of harmony to speak of the situation as a "boom in Peonies," has brought so prominently to the front the question of size of roots sent out to customers, that it is only second in importance to the question of true stock; that is, the securing of varieties true to name.

The question needs some expounding. Inasmuch as fair and honorable competition is desirable, it is to be regretted that some growers have obscured the situation by employing ambiguous terms in quoting size of roots. Thus the sizes named as "divisions," "small," "medium," "large," and even "one year old" and "two year old" roots are meaningless, unless the customer has a knowledge (perhaps from previous purchases) of that particular grower's "version" of just what these terms mean. The word "division" as applied to Peonies is a trade term, but it seems to be a very elastic one with some growers, and there is opportunity for much misrepresentation. A more or less mature plant is taken up and divided, $i$. e., cut into pieces. These divisions are either replanted, by way of propagating, or sold as divisions as the case may be. But a grower in dividing may cut the plant into VERY small pieces. The point we wish to make is obvious, which is, that not only is there no standard for the size of a division, and the piece of root you get depends upon the liberality of the grower, but also the more important fact, that one of these tiny divisions replanted by the grower is, after one or two growing seasons, sold as a one- or two-year plant-which, strictly speaking, it is-yet it will not by then have attained the size or worth of a large division sent out by a more liberal firm. It is plain, therefore, that as there is no fixed standard for 


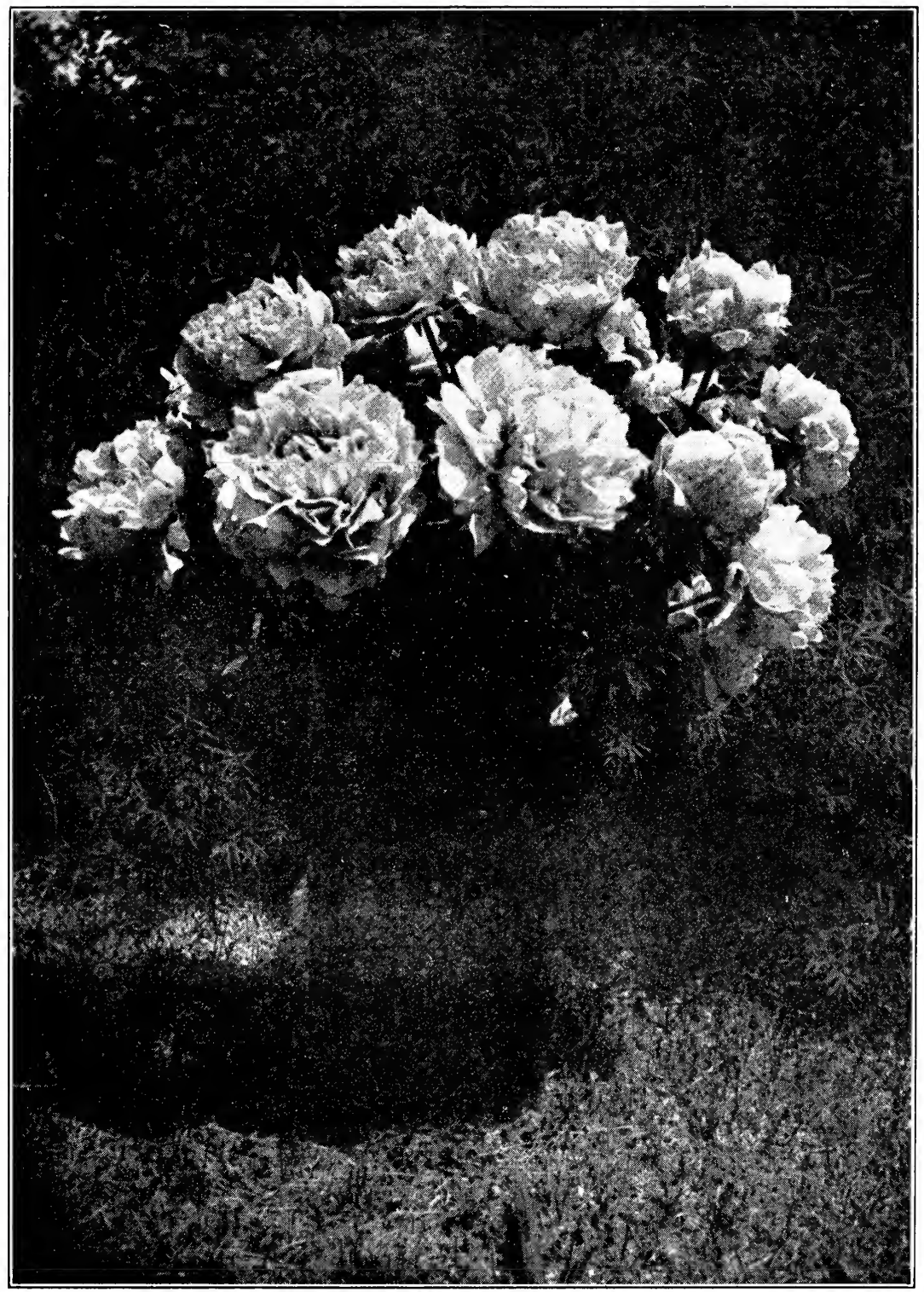

LIVINGSTONE; ENORMOUS, MASSIVE, COMPACT; A PEONY OF THE HIGHEST CLASS. 
the size of a division, the listing of roots as one year old, or two years old, does not indicate their value, unless the buyer has confidence in the grower's liberality in cutting the original divisions.

\section{Our Prices and Grade of Stock}

Eliminating all this misleading, if not actually deceptive listing of "one-year" roots, "two-year" roots, etc., we quote but one grade of plants. Should you decide to favor us with your valued order, you will, we believe, be surprised at the quality of stock we send out. For we mean to continue our liberal policy, by reason of which our business has been doubled and doubled again in recent years. Our system of "dividing" and growing is such, that we are able to send out plants that cannot fail to satisfy the most exacting buyer. The stock we deliver is heavy, vigorous, liberally grown quality stock that will-if properly planted-produce a very satisfactory amount of bloom the first season. It is the kind of stock which some "specialists" and nurserymen would call "two-year," and even "three-year" plants, and would send out as such-if they had it -at corresponding prices. Every assortment of plants we deliver, will be practically of a uniform grade (blooming quality). Customers should bear in mind, however, that variations in mere size or "bulk" do not always indicate variations in blooming quality, since varieties differ somewhat in habits of growth. The only exceptions to the grade of stock we promise to supply, are the few sorts listed in Sections 7 and 8 . Purchasers of these sorts must be content with smaller roots on account of the extreme scarcity (NOT SUPERIORITY) of the varieties.

In soliciting your valued patronage, therefore, we ask a careful consideration of the points we have made, especially in comparing our prices with those of other growers. We know that our rates, considering the grade of roots we offer, are, to say the least, as low as the same grade of TRUE stock can be had elsewhere.

WE ARE STRICTLY RETAIL AND OUR PRICES NET AS QUOTED, EXCEPT THAT ON ALL ORDERS WE ALLOW THE FOLLOWING

\section{DISCOUNTS}

\section{When Cash Accompanies Order}

\section{(COLLECTION OFFERINGS EXCEPTED)}

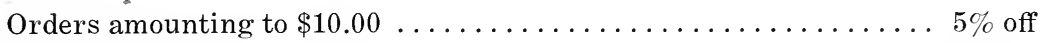

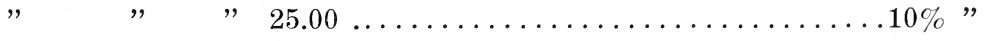

$" \quad " \quad, \quad 50.00$ and upwards $\ldots \ldots \ldots \ldots \ldots \ldots \ldots \ldots \ldots \ldots$ 


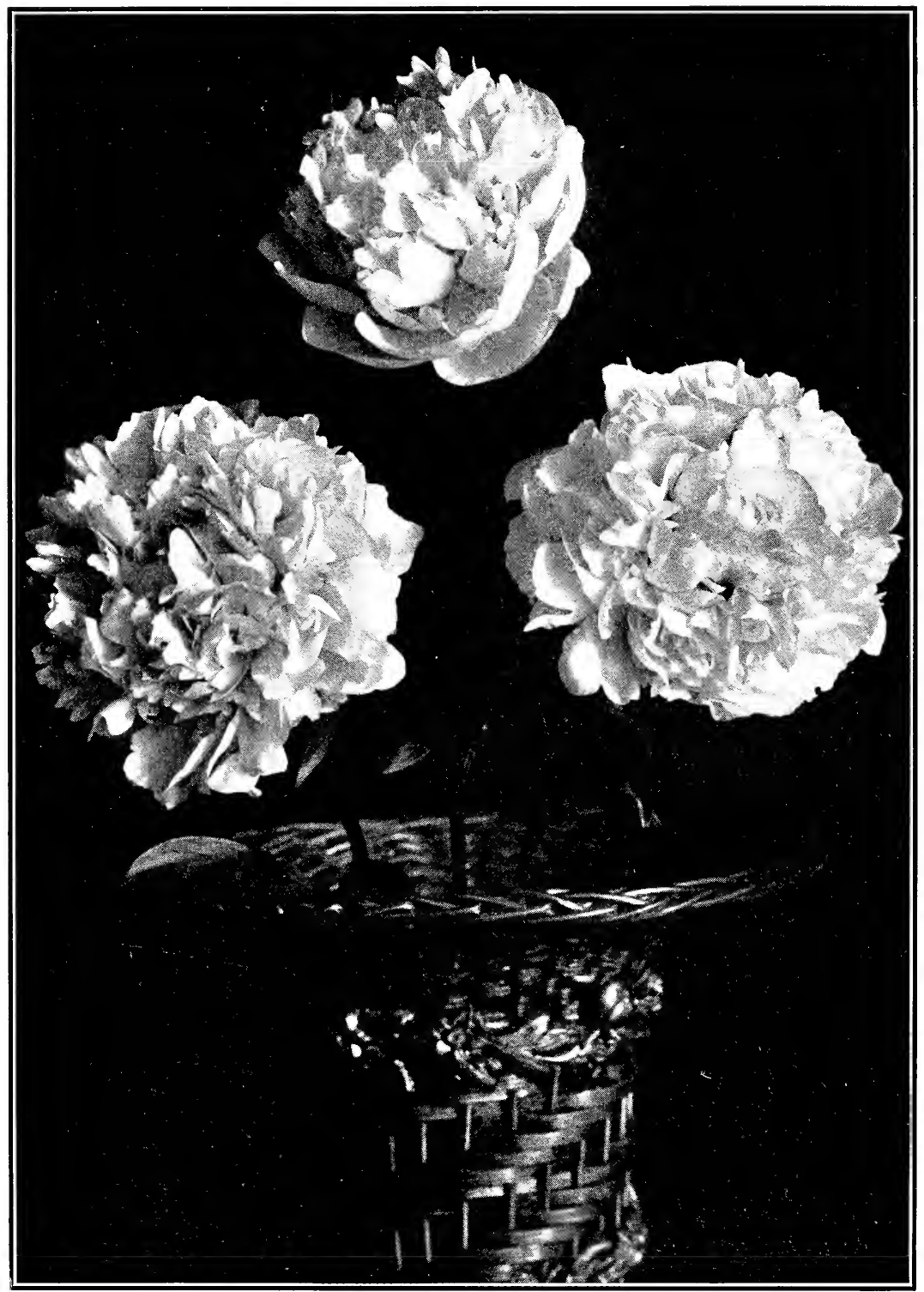

THE INCOMPARABLE "EUGENE VERDIER"

We consider this the greatest Peony in cultivation. Three other inferior sorts are being sent out under the name. 


\section{Packing, Shipping, Etc.}

\section{EVERY ROOT SENT OUT IS DUG, LABELED AND PACKED UNDER MR. KLINE'S PERSONAL DIREGTION}

WE DO NOT QUOTE ANYTHING THAT WE ARE AT ALL LIKELY TO RUN SHORT on; consequently it is not necessary for customers to caution us against substituting, which we never do under any circumstances.

Roots carefully packed will be sent either by express or freight as purchaser may desire. We strongly advise, however, against freight shipments, for altho' plants sent in this way will reach you in first class condition, there are often irritating delays, especially on long distances. For plant shipments the express companies allow a special twenty per cent. discount from the general rate for merchandise, so that express rates are not excessive.

In all cases we pack as lightly as is consistent with safe carriage.

\section{POSITIVELY NO PLANTS CAN BE SENT BY PARCEL POST.}

No order filled for less than one dollar.

No goods sent C. O. D. unless remittance is received for half the amount of the purchase. No deviation from this rule.

Remittances may be made by check, cash in registered letter, express money orders, or Post Office money orders on Sinking Spring, Pa.

\section{MAKE ALL ORDERS PAYABLE TO THE MOHICAN PEONY} GARDENS. Those desiring to open an account must furnish satisfactory reference, which it must be remembered will take some days to investigate.

No account opened for an initial order of less than ten dollars.

Give your complete express or freight office and Post Office address, write the same as well as your name distinctly, and to promote the correct filling of your order, PLEASE USE ORDER SHEET ATTACHED IN THIS CATALOG.

Very respectfully yours,

MOHICAN PEONY GARDENS, Sinking Spring, Pennsylvania. 


\section{OUR COLLEGTIONS}

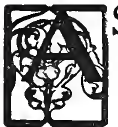

S HAS already been suggested, our list of one hundred sorts - a list which from every point of excellence we deem it impossible to surpass - it is believed will supply the wants of any possible Peony enthusiast. On the opposite page, however, will be found four special collections. This is a part of our original plan of simplifying matters for those who know little and care less about Peony nomenclature but who want the choicest and best things in cultivation. These collections have been arranged in no haphazard fashion nor to fit the amount of stock we have of certain sorts (as is frequently the case in "collection offerings"), but we have taken the one hundred varietieswhich we deem the best hundred in existence--sorted, sifted, boiled them down, as it were, and these four collections are made up of the very cream of our fields. They cover the entire range of form and color. We guarantee them the very best and most desirable in cultivation. That is to say, in size, perfection of form, fragrance, vigor of bloom, and in lasting quality as cut flowers, they equal any, and surpass most, other known kinds. We will stand by this assertion, and we challenge comparison with any other twenty-five varieties. 


\section{THE COLLECTIONS}

PLEASE NOTE: Under no circumstances can we make substitutions or changes in these lists; please do not ask it. The collections are intended primarily for those who wish to be guided in their initial purchase of Peonies, and who naturally want the best varieties. Patrons who have already had these collections and desire other varieties from the general list, may avail themselves of our liberal discounts offered on page 21 ; but we cannot accept orders for "collections" of the purchaser's own arrangement based on these schedules, nor, as before stated, for any changes whatever in the lists.

\section{COLLECTION No. 1 25 VA RIETIES 0ur Challenge Collection} Covering the entire range of Form and Color, and Unexcelled from any point of view by any 25 Sorts in Existence

Albert crousse ............. 1.50

Alexandriana $\ldots \ldots \ldots \ldots \ldots \ldots \ldots . .50$

Alice de Julvecourt .......... .50

Claire I)ubois ............... 1.50

Couronne d'Or ............ .75

Erlulis superba ............ 35

Eugene Verdier ............. 2.00

Felix Crousse ............. .75

Festiva Maxima ............. .60

Floral Treasure ............. .50

Gloire de charles (xombault ..... 1.50

.Jeanne al'Ale ............... .60

Livingstone $\ldots \ldots \ldots \ldots \ldots \ldots \ldots \ldots .1 .00$

Madim Bucquet ............. 1.00

Marlam de Verneville .......... .75

Madam Ducel ............... 1.00

Madam Enile Galle ........... 1.00

Madam Forel ................ .75

Marlam Geissler ............. 1.00

Marie Lemoine ................ 1.00

Modeste Guerin ............ .75

Monsieur Dupont ........... . .75

Monsieur Jules Elie ............. 1.00

Sourenir de L'Exposition de Bor-

deaux $\ldots \ldots \ldots \ldots \ldots \ldots \ldots \ldots \ldots .6 \ldots$

'Triomphe de L'Exposition de Lille .75

$\$ 23.30$

THE COLLECTION FOR $\$ 18.00$

\section{COLLECTION No. 2}

BEST 15 VARIETIES

Albert Crousse ...............\$ 1.50

Claire Dubois $\ldots \ldots \ldots \ldots \ldots \ldots \ldots \ldots \ldots \ldots$. 1.50

Erlulis superbal ................

Eugene Verblier ............. 2.00

Felix Crousse ..............

Festiva Maxima .............

Gloire de Charles Gombault..... 1.50

Eivingstone .................. 1.00

Madam Pucquet .............. 1.00

Madam de Verneville ...........

Madam Emile Galle ............. 1.00

Madim Geissler ............. 1.00

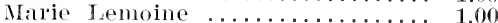

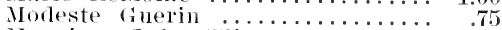

Monsienr .Jules Elie ............ 1.00

THE COLLECTION FOR $\$ 13.00$

\section{COLLECTION No. 3} BEST 10 VARIETIES

Allert Crousse ............\$ 1.50

claire Dubois ................... 1.50

Eugene Verdier .............. 200

l'elix Crousse ............. .75

Festiva Maxima ...............

Madam Bucquet .............. 1.00

Matam Emile balle ........... 1.00

Madium qieisslei ................ 1.00

Marie Lemoinc ................. 1.00

Monsieur Jules Elie ............. 1.00

$\$ 11.3 .5$

THE COLLECTION FOR $\$ 9.50$

\section{COLLECTION No. 4 \\ 5 VARIETIES}

Alice de Julvecourt ..........\$ .50

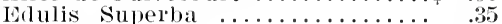

Felix Crousse ............. .75

Festival Maxima $\ldots \ldots \ldots \ldots \ldots \ldots \ldots \ldots . .60$

Madam Forel .............. .75

THE COLLECTION FOR $\$ 2.00$

NOTE-Collection No. 4 is not meant to be a selection of the best five of the twenty-five. It includes, however, some of the very best and most generally satisfactory of those on the Challenge List. 


\section{THE GENERAL LIST OF}

\section{One Hundred Varieties}

The name in parenthesis following the variety is that of the originator.

\section{SECTION 1}

\section{5 cents each}

BEAUTE FRANCAISE (Guerin). Very pretty flower. Pale lilac-rose with creamwhite collar; center flecked crimson. Fragrant mirl-season bloomer.

BOADICEA (Unknown). Creamy white; cupped center. Very interesting and pretty low-priced white Peony.

CHARLES VERDIER (Doubtful). Very large rose-type bloom. Lilaceous carmine with pink reflex. A late very free bloomer and deliciously frigrint.

DOCTOR BRETONNEAU (Verdier). Bomb-type. Even shade of bright pink and a very free bloomer. Excellent for cutting and mass planting. Fragrant. Mid-season.

EDULIS SUPERBA (Lemon). Very beautiful, large, full, and well-formed bloom, with good culture measuring from seven to eight inches across. Brilliant violaceous pink with silvery reflex. A vigorous grower producing quantities of very fragrant flowers on strong stems. Because of its extreme earlinessrarely failing to be ready on Memorial Day,-together with its general superior merit, this is really one of the most valuable Peonies we possess. Its low price is due to the fact that there is considerable stock of it in existence.

GENERAL BERTRAND (Guerin). Large, conpact, globular. Beautiful shade of pink. Strong grower. Early mid-season. Strangely enough this variety has been confused by some growers with Modeste Guerin. It is totally unlike that variety.

HENRI DEMAY (Calot). Superb violet purple, lighted with whitish reflex. Large and full bomb-type with center petals slightly fringed. Fragrant. Mid-season.

\section{SECTION 2}

\section{0 cents each}

ALEXANDriana (Calot). Very large globular and full double light pink with silver edges. An unusually strong grower, with great quantities of delightfully fragrant flowers on long strong upright stems. A fine early mid-season cutflower sort. In spite of its comparatively low price, one of the most valuable Peonies we have. 
ALICE de JULVECOURT (Pele). Magnificent, very double, perfectly built fragrant flower; soft pink, delicately shaded rose and cream, with central petals beautifully edged purple. An exquisite combination of coloring not easily described. A very free and rather early bloomer. We consider this one of the very finest Peonies of the light varieties in cultivation.

AUGUSTE LEMONIER (Calot). Velvety violet red; very brilliant. One of the best of the old standard sorts. Fragrant. Mid-season.

BERLIOz (Crousse). Large compact bloom. Currant-red, tinted rose and amaranth. Tips of petals fade to nearly wlite. Very effective. Late.

CANDIDISSIMA (Calot). Very beautiful, large and full double rose-type. Creamy white with sulphur center and green heart. Free bloomer. Fragrant.

DELACHEI (Delache). A very rentakable and striking dark Peony. Deep rich amaranth purple with a crimson reflex. Late, fragrant, a strong grower and a free bloomer. A fine sort for massing.

DUKE OF WELLINGTON (Calot). A rather late sulphur-white bloom and fragrant. It is a good keeper and highly esteemed by florists for that reason.

FLORAL TREASUIR (Rosenfield). An American production of very great merit, and a splendid "hemisphere of fragrance." Very large showy pale lilac-rose, on long strong stems. A vigorous plant, a wonderful late mid-season bloomer, an altogether ideal cut-flower variety. Very similar, but nevertheless superior' to "Delicatissina", which we do not offer.

FRANCOIS ORTEGAT (Parmentier). Large purplish erimson bloom, brilliant golden yellow anthers. Very striking and of much value.

MADAM BREON (Guerin). Guard-petals, a brilliant rosy-flesh; center creamy white or yellowish. Large blooms and exceptionally strong stems. Early and fragrant. Very striking and effective for landscape purposes.

MADAM LEBON (Calot). Immense, full, rose-type blooms, coming on long strong stems. Bright cherry-pink, with silvery tips. Fragrant mid-season.

MEISsoniER (Crousse). Large brilliantly-effective, bomb-slaped, purple-red. Fragrant mid-season. A very fine dark Peony.

MELANIE HENRY (Guerin). Attractive rose-type bloom. Light solferino-red, fading to pale pink. Fragrant, a vigorous grower, and free early bloomer.

POTTSI (Potts). Intense, very dark rich crimson. Very unique and attractive. Semi-rose type. Fragrant. Early.

\section{SECTION 3}

\section{0 cents each}

DUCHESSE de NEMOURS (Calot). Very large and full cup-shaped bloom. Sulphur-white with greenish reflex. Exquisite in the bud. A vigorous, free, early bloomer, delightfully fragrant, and a fine cut flower sort. 
EMPEROR NICOLAS (Crousse). Large, ball-shaped bloom. Tufted center. Color, brilliant amaranth with purple reflex. Very effective. One of the best reds.

FESTIVA MAXIMA (Millez). Unquestionably, this is the finest white Peony in existence. More than sixty years have passed since its introduction and it remains to-day unequalled in its class and color. It combines great size with wondrous beauty and the blooms come on strong upright $3 \frac{1 / 2}{2}$ foot stems. Color: pure paper-white, flecked with clear purple spots on the edges of center petals. In addition it is surpassingly fragrant which, together with the fact of its extreme earliness (it being the first white of real merit to bloom) places it among the very best of the eut-flower sorts. A truly regal flower impossible to adequately describe, and should never be omitted from any collection.

JEANNE D'ARC (Calot). A glorious flower,--a very "splendor of fragrant loveliness," very similar to "Golden Harvest," but larger, and finer, for which reason we no longer offer that variety. Collar, cream white, shaded with sulphur. Guards, pale lilac-rose, and full high brilliant pink center, witl occasional carmine spots. A vigorous plant, and a very free mid-sealson bloomer. Exquisite, and with the exception of "Gloire de Charles Gombalult," the very finest tri-color yet produced.

LA TULIPE (Calot). Large bloom on long stiff stems. Rose filding to a creamywhite with carmine stripes giving the flower a distinct tulip-like effect. Very fragrant and floriferous. Late mid-season.

MADAM CirAtMY (Calot). Large, full and compact true rose-type bloom. Pale lilac rose with silvery reflex and oceasional carmine matrings. A fine late very beautiful variety and a free bloomer.

MADAM de VATRY (Guerin). Splendid cut-flower variety and a fine bedding sort. Very large, finely-formed bloom. Guard-petals, clear flesh; center, sulphur-white with carmine stripes. Fragrant. Mid-season.

MATHIDE de ROSENECK (Crousse). Late, double, ball-shaped flower. Soft, flesh-pink, sharding deeper to center, with reflections of chamois. Petals bordered with silver, and some narrow carmine edgings. Very distinct.

MONSIEUR BOUChERLATAIN (Calot). Enormous full globular bloom. Bright rosy lilac with silver reflections. Fragrant. Mid-season. Beautiful.

RUBRA SUPERBA (Richardson). Deep rich crimson. Very large, double, and highly fragrant. The latest Peony to bloom. Rather a shy bloomer until well established, but purchasers should be patient as this variety is the best late black, and one of the best of its color.

\section{SECTION 4}

\section{5 cents each}

AGNES MARY KELIVAY (Kelway). Large and superb Peony. Deep violet rose with a cream white collar. A free mid-season bloomer. A worthy novelty. 
BERNARD de PALISSY (Crousse). Compact, globular eup-shaped bloom. Delicate blush pink fading to nearly white. Free late bloomer, and surpassingly fragrant. A superb variety.

BOULE de NEIGE (Calot). Very large and compact cup-shaped flower. Sulphurwhite, with central petals splashed with carmine. Fragrant; early.

COURONNE D'OR (Calot). A late, exceedingly fragrant, ball-shaped bloom. Snowy white with yellowish reflex and carmine edges on center petals. Incomparably lovely and one of the very choicest and hest Peonies in cultivation.

DeCANDOLLE (Verdier). Brilliant currant-led, tinged amaranth. Remarkably full compact bloom and very large. one of the really first-class reds.

DORCHESTER (Richardson). Beautiful and delicate salmon flesh; a well-built and striking variety. Rather a dwarfgrower, but blooms come on strong, upright stems. Very late, coming in after most other varieties have patssed.

EDOUARD ANDRE (Mechin). Early-blooming, deep brilliant crimson with metallic reflex and golden yellow stamens. Valuable and unique.

FELIX CROUSsE (Crousse). Enormous, massive, compact, and typical bombshaped red, with ruby-flamed center. Fairly dazzling in the brilliancy of its distinct color, it is in fact, the greatest red Peony in cultivation, and should be included in every collection. Free mid-season bloomer, and quite fragrant. Very similar but decirledly superior to Augustin d'Hour, which variety we do not offer for that reason.

LA ROSIERE (Crousse). Large, compact, globular flower, with broad, imbricated petals; straw-yellow at center with yellowish-white border. In form and effect resembles an enormous tea rose. A beautiful and valuable variety.

MADAM CALO'T (Miellez). Large, well-built rose-type flower. Pale pink with darker center and collar tinted silver. Fragrant. Early mid-season.

MADAM CROUSSE (Calot). Enormous very double late-blooming pure white, slightly edged in center with carmine. Very fragrant and one of the hest whites we have for cut flowers.

MADAM de VERNEVILLE (Crousse). Vary large, exquisitely beatiful, imbricated, bomb-shaped white. The guard-petals are pure paper-white and very broad, folding over the flower; center daintily suffused with blush and cream, and tipped carmine. The whole flower heavy and compact. Strong grower, a free bloomer, and early with a delightful sweet rose-like fragrance. A superb and remarkable bloom.

MADAM FOREL (Crousse). Immense, compact, ball-shaped bloom of striking effect. Clear deep rose of an unvarying color. Strong stems, very fragrant, and rather late. In every way, one of the best sorts in the catalog. 
MODESTE GUERIN (Guerin). One of the loveliest of them all, and of great allaround merit. Very large, full and compact. Snperb deep solid rose. Very free-flowering and fragrant. Exceptionally rigid stems, and very distinct fuliage. The true sort is unmistakably distinct, and it is rather remarkable that it should be spuriously offered, as it is, by certain other growers.

MONSIECR DUPONT (Calot). Immense milk-white beatifully built flower. Central petals tipped with bright carmine, and a few golden stamens discernible at their base. An exceedingly fragrant, free-blooming, late mid-season variety, coming on long stiff upright stems. One of the hest whites we have for eutting. A rich and rarely beautiful flower.

I'ETITE RENEE (Dessert). Large blooms in clusters. Collar of very broad petals, clear, carmined-purple; center petals narrow, clear, carmine-striped white. Striking, distinct and showy variety; and very searce.

POTTSII ALBA (Buyck). Flesh pink, bleaching desirably to white. A tall grower and free bloomer; an exceedingly beautiful variety.

SOUVENIR de L'EXPOSITION UNIVERSELLE (Calot). A very fragrant, full, clear cherry, with silvery reflex, strong grower and free bloomer. Extril fine.

TRIOMPIIE de L'EXPOSITION de LILLE (Calot). Large and compact flower of an odd and striking double-crown type. Very distinct. Pale hydrangea-pink, delicately mottled violet-rose. Strong grower, and very fragrant. Blooms late mid-season. A unique variety, but standard, and should be included in every collection of any considerable size.

UMBELLATA ROSEA (Unknown). The very ealliest Peony and therefore an excellent Memorial Day sort. Large blooms on long stems; fine bud and vigorous habit. Guards, an attractive pink; center, creamy-white with salmon tuft.

VIRGo maria (Calot). One of the few really fine pure paper-whites, without markings. Delicate and refined. Fragrant. Late.

\section{SECTION 5 $\$ 1.00$ each}

Atrosanguinea (Calot). Marvelous flower. Deep blood-red with metallic lustre. Early and free blooming. In form looks like an American Beauty ruse in the bud. One of the best of the dark Peonies. The true sort is searce and it is being offered wrong by many growers.

LIVINGSTONE (Crousse). Enormous, very massive, imbricated and compact bloom. Pale lilac-rose with silver tips; center petals flecked with carmine. A vigorous grower and one of the latest to bloom. Long strong stems. Exquisite in the bud, and a great keeper, but lacking in fragrance. A Peony of the highest class. Unquestionably one of the finest and most valuable sorts in cultivation.

MADAM BUCQUET (Dessert). A magnificent flower-a striking and remarkable dark Peony, and one of the best of the black sorts. Velvety black amaranth with garnet reflections. Medium in size, fragrant, strong grower, and free bloomer. Indispensable. 
MADAM CAMLLE BANCEL (Cronsse). Large, bomb-shaped convex flower, very full; glossy, lilac-pink, center with brighter reflex; salmon shadings. Bealutiful and distinct.

MADAM de GALHOU (Crousse). Large and full curved bloom witl closely set petals. Soft, glossy, flesh-pink petals bordered silvery-pink. Lovely variety.

MADAM DUCEL (Mechin). Enormous, globular and compact bloom. Literally packed with petals, which are somewhat incurved like chrysinthemums. A striking, brilliant shade of pink with silvery reflex. Holds its form and color to the end. Considered by many the very finest formed pink in existence. A magnificent cut-flower variety and wondelfully effective for landscape work. Stands among the very first on our "cluallenge list." Fragrant early midseason bloomer.

MADAM EMILE GALLE (Crousse). Large, cup-shaped, and imbricated bloon. Exquisite sharle of soft lilac, with milk-wlite center which slowly changes to prononnced cream-color. A refined and rarely lieantiful flower not easy to describe. A free bloomer and rather late.

MADAM GEISSLER (Crousse) Visitors to our fields invariably pause in astonishment before our block of this variety. The word "sensational" best describes Madam Geissler, and it is difficult to speak in temperate terms of this murelous flower. It is one of the very largest Peonies in existence; very double, globular. Imbricated, massive and imposing. Color: a glossy silver rose, shading to Bengal rose at base of petals. I elicious, and distinct fragrancediffering from nearly every other variety in this respect. An abmuant mialseason bloomer, heavy and perfect flowers coming even on the youngest plants. An ideal-keeper, and therefore one of the best cont-flower sorts. The only fault of this Peony is, that the stems are not as heary as they should be to upholal the massive blooms. The true stock of the variety has become rather scarce, and many growers do not attempt to offer it.

MADEMOISELI. RENGE DESSERT (Mechin). Immense flowers in alusters; a superb shade of lilac, with violaceous reflex. Very attractive.

MARIE LEMOINE (Calot). This is the absolutely indispensable Peony to any collection, large or small. Fxquisitely beautiful, enormous, massive and solid ivory-white, deepening to chamois toward center, and very occasionally tippeal with carmine. Invariably a six to seven inch flower, even under indifferent cultivation. Fragrant, and a free bloomer on extra stiff erect stems, it is the very latest white to bloom, and particularly valuable for that reason. A magnificent variety, but so slow to increase, that the genuine thing is still very rare, altho it is offered everywhere, and at all sorts of prices.

MODELE de PERFECTION (Crousse). This is one of the late bloomers and very fragrant. Color clear flesh-pink, marked with bright rose and bordered with silvery rose; large guard-petals forming high glolular buds.

MONSIEUR JULEs ELIE (Cronsse). Immense globular, very full, double, imbricated bloom on very heavy stems; petalage broad and over-lapping, forming one of the most perfect specimens imaginable; color, an ideal glossy fleshpink, shading to deeper rose at the base and the entire blooms covered with a silvery reflex. A vigorous grower, free bloomer, rery fragrant. Scarcely rivaled, either for cut-flower or landscape work. 
MONSIEUR KRELAGE (Crousse). Latrge, full flower; deep solid red, with tips lightly silvered. Very fragrant. Late.

OCTAVIE DEMAY (Calot). Large, and well-built flower. Light shell pink, with a few carmine stripes in center and a large guard. Early and fragrant.

SOLFATARE (Calot). Large, full and fragrant bloom. White guard petals, center narrow and sulphur-yellow. Quite distinct. Mid-season.

VAN DYCK (Crousse). Outside petals, rosy lilac; inside, silmon shaded rose, with here and there a crimson spot. Very fine and striking. Frialant.

\section{SECTION 6 $\$ 1.50$ each}

ALBERT CROUSSE (Crousse). One of the most striking, and perhalps the most distinct Peony in existence, there being nothing clse of just the same form ind character. Immense bloom, very full and compact; small imbricated, and very dense petalage from the outside to the very heart of the flower. Flesh-pink, lightly reflected lilac, with center shaded clear pink. In color and form, like an enormous flesh-pink carnation. Very sweet fragrance. Tall, erect in growth, and a late bloomer. A superb and an extraordinary Peony.

ASA GRAY (Crousse). Immense massive and compact bloom; imbricated like a rose; very full and fine of form. Pink very delicately dotted with carmine. An imposing and extraordinary flower and very fragrant.

AUGUSTE VILLAUMe (Crousse). Very large and full peony-formed bloom, with closely set petals; deep pink; fine, vigorous habit; late; splendid variety.

AVALANCHE (Crousse). Large, glorious bloom of perfect form; fille, milk-white; creamy center, with a few ruby marks.

ClamRe DUBoIs (Crousse). One of the very largest Peonies in cultivation. Immense, solid, globular. Center very full, convex, and tufted; petals incurved and lacinated. Exquisite clear, deep violet-rose with a satiny reflex. Very tall and a late bloomer. A superb impressive flower.

CONSTANT DEVRED (Calot). Large full compact flower; striking shade of violet. An effective landscape sort and very lovely as a cut flower. Late.

GLOIRE de CHARLES GOMBaUlt (Gombault). This Peony is distinctly first and foremost of the multicolor varieties. It easily surpasses them all, and standing upon its own merits, we consider it one of the most strikingly beautiful varieties on our list. Large, globular flowers, extra dense and compact. Deep fleshy pink collar; narrower center petals of salmon and apricot, touched here and there with bright carmine. Fragrant mid-season bloomer on extra long stout stems. Ideal for cut flowers. "Simply delicious" is the way a visitor to our grounds described this variety.

GRANDIFLORA (Richardson). Exquisite flesh pink, with somewhat lighter shades in center. One of the very largest Peonies, and the latest pink to bloom. Fragrant. 
LAMARTINe (Calot). Enormous compact bloom. Pale lilac rose. Very delightful spicy fragrance. Free mid-season bloomer. Formerly known as Gigantea.

MADAM FOULD (Crousse). Very full and compact, flesh-white; fine form and build; rare and fine.

MADEMOISELLE ROSSEAU (Crousie). Large full flower with milk-white guard petals and pinkish center. Free mid-season bloomer. A worthy sort.

MARGUERITE GERARD (Crousse). Very large bloom with broad petals; fleshy color, changing to a very soft fleshy-white; creamy-white center. Exquisite free-flowering Peony and very rare.

QUEEN (Kelway). Large globular compact rose type. Uniform rose-color. One of the most beautiful varieties of English origin. Late.

SOUVENIR de L'EXPOSITION de BORDEAUX (Dessert). Medium-sized, globular, bomb-shape; very round and full, and of an extraordinary color; a bluish violet, or wine color that does not fade out under the most glaring sum. We consider this one of the most distinct and remarkable Peonies that has yet been introduced. There is nothing else just like it in color and it should be included in every collection. Rare, and difficult to obtain true.

\section{SECTION 7}

\section{$\$ 2.00$ each}

ADOLPH ROssEAU (Dessert). Very large and purple garnet with metallic reflex. One of the darkest reds and the first of its color to bloom. Very distinct.

AURORE (Dessert). Cup-shaped flower; soft, flesh-pink, salmoned yellow at base of petals, with numerous golden stamens intermixed. superb and scarce.

BARONESS SCHROEDER (Kelway). Flesh chinging to white, and a free bloomer. Exceedingly rare. Not to be had anywhere in any quantity.

COQUELIN (Dessert). Very early-blooming cup-shaped blooms. Bright chinapink with silvery border. Very rare.

EUGENE REIGNOUX (Dessert). Early blooming and very rare sort; large cupshaped flower; brilliant carmine, pink shaded, purple at base.

EUGENE VERDIER (Calot, but NOT the Dessert variety). After twelve years' experience with this variety, we see no reason to qualify our early estimate of it in the slightest degree. We consider it the most exquisite, chaste and refined Peony of the whole fanily, - in short, THE greatest Peony in cultivation. It combines every desirable feature, and is absolutely without fault or blemish. Enormous size, compact and globular, it is crowded to the very heart of the flower with petals of the most exquisite texture. Color: blush. very delicately shading to deeper pink toward the center. A vigorous, profuse early bloomer, and deliciously fragrant, with long thick stems to uphold the big flowers which last an extraordinary length of time, either on or off 
the plant. The genuine sort is exceptionally rare, and all of the above-named features will not apply to the several substitutes that are being supplied by most growers, in place of the sort which we offer. We have no hesitancy in saying, that as a cut flower and for decorative purposes, this Peony is unequalled by any chrysanthemum ever grown.

GERMAINE BIgOT (Dessert). Recent production and one of Dessert's finest triumphs. Large flesh-colored, shaded salmon. Very fine.

GRANDILLRA NIVEA I'LENA (Lemon). A very early and superb Peony. Large and full; pure white collar; center, shaded salmon and sulphur. Fine and extra desirable.

RUY BLAs (Dessert). Enormous full globular; lovely china-pink with broad, silvery border. Very brilliant and effective. Rare variety.

SIMONNE CHEVALIER (Dessert). Very large and globular and extra full; guards delicate, silvery-pink; petals in center, narrow and soft, salmon-pink glazed lilac. Comes in clusters; rare and distinct.

\section{SECTION 8}

\section{PRICES AS NOTED}

LAFAYETTE (Densert). Large imbricated flower with fringed petals; velvety purplish-pink with silvery petals. A recent production of great merit. $\$ \mathbf{3 . 0 0}$.

LA TENDREsSE (Crousse). Very full double, immense flowers; cream, changing to white. liare and fine. $\mathbf{\$ 3 . 0 0}$.

MADAM AUGUSTE DESSE'T (Dessert). Large, imbricated, cup-shaped flower; magnificent form; rounded petals, glossy, flesh, shaded, clear carmine. Beautiful. $\$ 4.00$.

MADAM EMLE LEMOINE (Lemoine). Lnormous and superb flower; soft pinkish-white with fleshy center. Exceedingly rare. \$3.00.

MARCELLE DESSER' (Dessert). Inmense flower's of perfect form; glossy creamy-white spotted lilac. Fragrance of a tea rose. Fiue habit, pretty foliage. Very desirable. $\mathbf{\$ 4 . 0 0 .}$

MARIE Crousse (Crousse). Exquisite, large, globular flower, very full; soft salmon-pink, slraded, glossy lilac; rale. \$3.00.

MONSIEUR MAR'TIN CAHUzac (Dessert). The darkest Peony in existence; almost black; brilliant black maroon with metallic reflex. Large flower of fine form; rounded petals; plant of erect and ideal habits; extralordinary flower and very difficult to obtain. $\mathbf{\$ 5 . 0 0}$.

THERESE (Dessert). Exquisite and very scarce sort of recent production. Large cup-shaped imbricated flower; glossy-flesh, delicately shaded-pink. Blooms in clusters. $\$ \mathbf{5 . 0 0}$. 


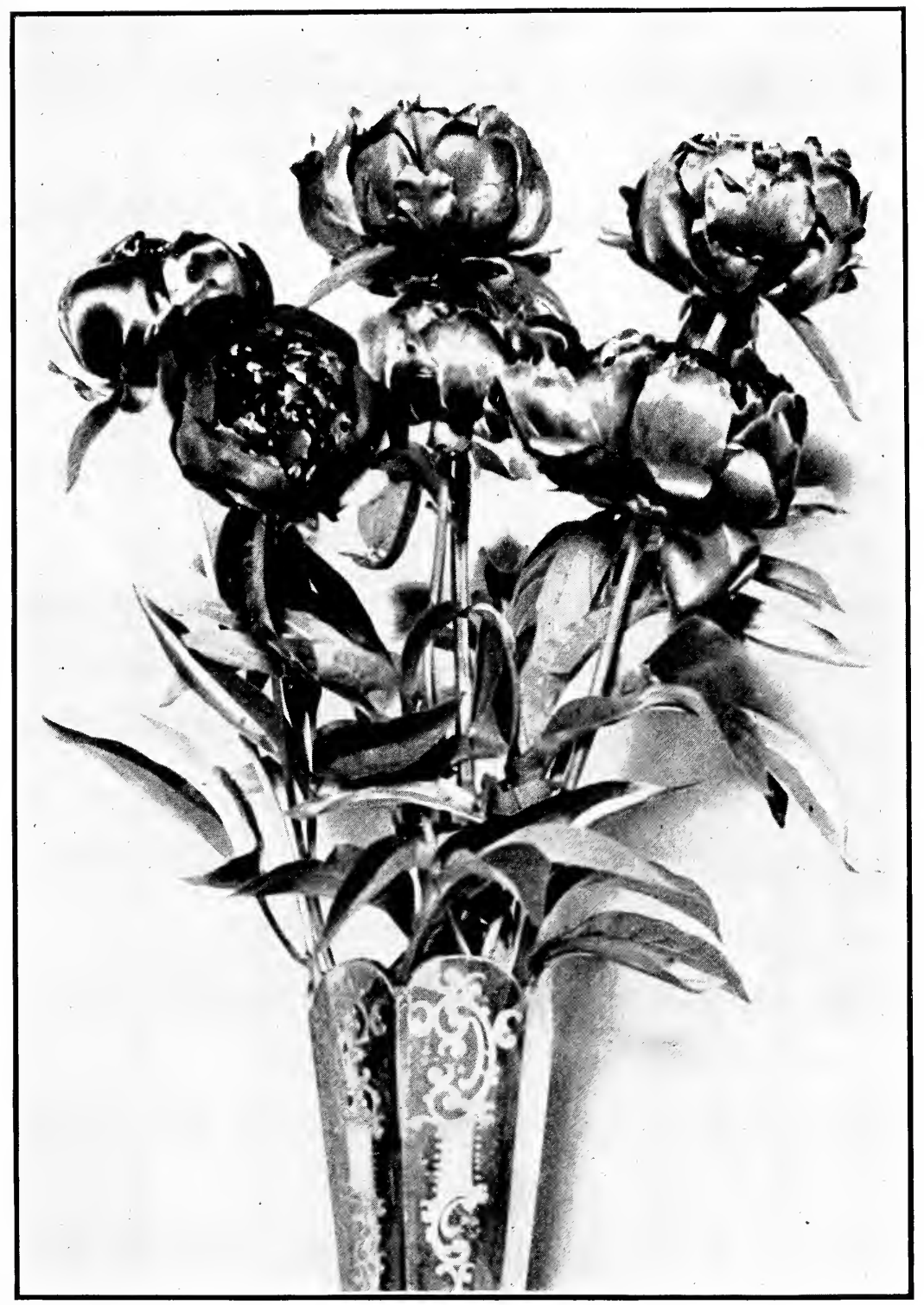

MADAM BUCQUET

One of the best of the blacks. Velvety black amaranth with garnet reflections. Fragrant, strong grower and free bloomer. 


\section{EVIDENCE}

We never publish names of correspondents. We never even ask permission to do so, since we dislike the idea of subjecting our customers to the publicity, to say nothing of the annoyance, resulting from importunities by mail from dealers in all sorts of merchandise. The following extracts from a few of the many letters of appreciation which have reached our desk were absolutely unsolicited. Glad to supply names-to any one interested-on request.

From sterems Point, Wis. (1915) - "I am enclosing an orter for more Peonies this fall. I have had plants from other lealers, lout never any that blossomed as yours did the first year. On twelve plants there were over one hundred blooms, as large and full, as those on plants which were set out two years before."

From. Pcoria, Ill. (1915) - "I have hundreds of Peonies, and the best I have ever had were those I purchased from you, and they all bloomed the first season."

From Providence, R. I. (1915)—"I enclose check in payment of your bill for Peonies, $(\$ 250.00)$ and I want to advise you that this is the nicest lot of roots I have ever received in my life. I thank you for taking the care in selecting them, and for the magnificent plants you have sent me. I shall be glad to have you refer to me at any time, and it is needless to say that when any of my friends want Peonies, there is only one place to which I can consistently recommend them, and that is your establishment."

From Avon, N. J. (1915)—“My blooms this year were a thing of joy to behold. Your roots are of the highest class I have ever purchased."

From Duluth, Mimn. (1915)—“The box of Peonies arrived in perfect condition and were the wonder of all who saw them. They were three or four times as large as those received from and - and - I shall certainly recommend sou to all of my friends, and send to you whenever I want Peonies in the future."

From Memphis, Tenn. (1915) — "I have certainly praised your Peonies. Not one of mine failed to bloom. One bush carried 21 pink Peonies all in bloom at one time. They have been the talk of Memphis."

From Darby, Pa. (1915)_"The Peonies purchased from you wonfor me two first prizes at the Lansdowne flower show, one of these being for the 'best individual Peony in the show.' I can conscientiously recommend your stock as being the very best obtainable."

From Tecumsch, Mich. (1915)_-“The Peonies which I purchased from you have done splendidly and have been admired by everyone. They have this, their second season, produced from 8 to 22 fully developed blooms on each plant. Of the roots purchased last fall, all but one have blossomed. The Marie Lemoine is certainly royal."

From Toronto, Canada (1914) — "I am not in the habit of writing testimonials, but I cannot refrain from commenting 
on the Peonies I had from you last fall. I recognized the roots as something exceptional, but my biggest surprise came with the results this spring. Rubra Superba did not bloom, and I could not expect it would, but the remainder had from two to ten fine blooms each. I am looking forward to receiving your cata$\log$ for this year, as I wish to order more."

From Goderich, Canada (1914)—“Of the 40 varieties I got from you last fall, every one bloomed this spring, and every one of them was true to the description given. You do not sufficiently praise such varieties as Avalanche, Baroness Schroeder, Madam Ducel and some others, and you cannot say too much for EITGNE VERUIER."

From Monticello, Iowa (1914) - "I placed an orrler this year with a certain grower for 'large undivided clumps,' at a price much in advance of his listed price, the irlea being that I was to pay an extra price for extral sized plants, and it is due you to say, thit those I had from you were fully as large, if not larger than those obtained from the other source. When desiring Peonies in the future, I shall surely place my order with you."

From Superior, Neb. (1914) - "Permit me to say, that every spring my enthusiasm over your Peonies increases. Two years ago we purchased from you, and every variety has proven all, and more than you have claimed for them, in size, perfect forn, and surpassing loveliness."

From St. Louis, Mo. (1914)—“My head gardener reported last year that every one of the 25 plants were as fine as any he had ever seen, and I take pleasure in advising you that every one bloomed satisfactorily this year. For that reason I am limiting my Peony orders this year to your Gardens,--instead of 'shopping around.',

Froul Mimeapolis, Minn. (1914) _- "I want to take this opportunity of expressing my extreme satisfaction in acknowledging receipt of Peonies. To put it mildly I was astonished at the size and sturly growth of the roots sent me. I counted twelve strong good eyes on one plant and thirteen on the other. When in need of Peony roots in the future ron can be assurea of my order."

Froul Utica, N. Y. (1914)-“I am writing to thank you for the strong healthy roots you sent me. They were the finest lot of Peony roots that I have ever seen shipped by any grower. In the future I will take pleasure in recommending your firm for fair dealings and good stock to all my friends who may want Peonies."

From. Plitadelphia-" rrankly, I do not know how to aderuately express my feelings in the matter of the roots that came today. They are so disproportionately greater than any I have ever received hefore from other growers at similar prices, that I most sincerely regret that I was too late to purchase from you last season. To any one over 45 , the getting results quickly is an important item, and to feel that I will have to wait for a couple of years for results from other roots that I have purchased elsewhere in the meantime, before they equal yours, is exasperating, and I have no one to blame but myself or the other fellow's advertiser."

From Wimipeg, Canada-"The seventy seven varieties of Peonies you sent me this fall, and which completes the humdred listed by you, came to hand while I was absent from home, and the gardener, with over twenty-five year's' experience here and in England, reported on my return that he had never seen such fine roots sent out by any grower. From the reports I have had from others, I quite concur in his good opinion." 
From Williamsport, Pa._-"Your Peonies came to hand in excellent condition. I had previously bought from four different growers and was certainly surprised at the size of the roots you sent. They are really not roots, but clumps, and, as no doubt you hear from customers if everything is not right, I thought on the same principle you were entitled to some appreciation when shipments come in that exceed expectations."

rrom Goderich, Camada-"The Peonies have arrived and $\mathrm{I}$ am certainly well pleased with them. You certainly have given me gool value for my money judging by the roots I have had from other growers."

From Plainficld, N. J.- "Before I sent my first order to you last montli, I had alrearly placed an order with

After an exasperating delay, the roots arrived today, and are so small and poor that I lo not care to plant them. I lope it is not too late to send me tle following. $* * * * *$ In the light of a witler experience,-three orters for Peonies having been placed before I tried your stock-I wish to compliment you on the quality and condition of your plants, and the promptuess and carefuhness of your shipments."

From Grand Rapids, Mich. - "I unpacked the Peonies yesterday, and if all aive the account of themselves next spring that they look capable of doing, I will be more than satisfied. All the roots were heavy clumps, and some might be easily taken for three and four vear plants; in fact I believe they were."

From Lansing, Mich. - "Permit me to say that I have a fairly representative collection of Peonies,--some sixty odd varieties, collected both in this country and in Europe; but for large thrifty stock, yours exceeds by far anything I have ever purchased."
From. Beverly, Mass." "I must say that they are the finest one-year plants I ever saw. I have purchased Peonies from nearly all the prominent growers and yours are far ahead in size and vigor.",

From. Highland Park, Mich.- "If all the seed and plant husiness was conducted in the manner that yours is, we might all have better gardens, with less trouble and expense."

From lit. Vernom, N.Y.- "It affords me much pleasure to thank you for the I'eonies forwarded to me last fall. They have been an overwhelming success. I have never seen such a profusion of hloom, nor handsomer flowers. I am referring several of $\mathrm{my}$ friends to you, and I have no doubt if you treat them as you did me, your business is bound to grow. I should in fact go out of $\mathrm{my}$ way to give your name to any of my acpuaintances, for I think an industry of the kind of which you are the head, should be assisted to the very last degree, and I am sure my friends will get harrels of pleasure and satisfaction out of any transactions with you."

From Chicago, IIl. - "When you told me you would supply blooming roots I was somewhat doubtful, as I had been 'stung' so often by other dealers who sold me four-year clumps, and promised a profusion of bloom, but never a flower did I see in three years. So it certainly is a pleasure to find one firm in the Peony business which tries to see how much instead of how little it can give for the money."

From Santa Cruz, Cali.--"The Peonies this year are very fine. I have never seen such bloons. You sent me 24 varieties, and every one of them has come to very near perfection. No one about here has ever seen any that compare with them." 
From Bromxville, N. Y.-"I desire to express my pleasure, and I may add surprise, at the fine size and quality of the Peonies you sent me. If they fulfill the expectations their appearance has aroused, I shall be more than ever discontented with those I have had from other sources. Limitations of space alone restrain my impulse to order the entire list in your catalog. Others promise, you keep your word."

From sparkill, N. Y. - "The Peonies came in fine condition and I wish to express my thanks to you for sending me such a lot of plants. If buyers knew the kind of stock you send out as compared with plants sent out by some of the other I'eony growers, you could not grow enough stock to fill your orders, Actually your plants are about as heavy now as some from _ that have been plinted two years. Wishing you every success, __. ,

From Arlmore, Pa. - "I am so very well pleased with the twenty-two Peonies just received from you, that I send the enclosed order for twenty more that I had intended placing with —. The one-year stock from _- - cannot compare with what you sent me in any way. Your roots are two to three times larger; had four times as many eyes, and your packing was done in a very intelligent manner."

From Ottawa, Canada- "All of the Peonies you sent me last fill bloomed this spring, as did those I got from you the year before. They were all true to name, which I consider worth mentioning, as this has not been my experience with those obtained from some other growers."

From Chicago - "It is a pleasure for me to acknowledge the receipt of the
Peonies, and to thank you for sending such fine sturdy plants. They are well set with phump eyes and quite different from those usually seen in these days of the 'commercialization' of the Peony."

From Kansas City, Mo.- "I have had splendirl success with the Peonies orrered from you. * * Fifteen blooms the EIGENE VEIDIER this spring, some of them nine inches in diameter, and none less than six inches. All the others have done well and are more thall satisfactory."

From ltica, N. Y. . "I bought ten Peonies from you, and while they bloomed the first spring, this was the banner rear. Such a sight as they were this real - one mass of bloom. - Alice de Julvecourt had 48 perfect flowers, some of them seven inches in diameter."

From Harisburg, Pa._- "Your collection of 25 varieties weighed 89 pounds when received. Any other 25 roots I ever bought would not have weighed over nine pounds. So rou can imagine my surprise and pleasure. The blooms were the finest. You sure have the varieties, and are not afraid to send out hig roots. I can't see how you (lo it."

From colar liapids, Ia.- "The description in your catalog of 'Eugene Verdier" is not a bit too strong; in fact you could ard more to it. Every one who saw mine in bloom, said it was the most beautiful Peony they had ever seen."

From st. Joscph, Ho._- Last fall I purchased your Collection No. 3 -ten best varieties *** Every one of the ten produced blooms this spring. You say the flowers will improve each year, 
but I do not hope for anything finer than the flowers produced this first year.",

From Palmyra, N. J.-“Judges of Peonies who saw the plants I had from you last fall in bloom this June, could hardly believe that they had been planted only last fall. I will say, too, that one-half of my bed of Peonies were purchased from another grower, equal space, same advantages, planted on the same day, and except in a single instance, they were not to be compared to yours."

From Centreville, Md.-- My little garden is a glorious sight, made so by your Peonies. The first collection sent me by you has produced magnificent blooms, and the Eugene Verdier cannot be beaten. It is grand."

From Colal Rapirls, Ia.- "The I'eonies arrived last Friday, and I found them perfect, and far superior to any that I have ever bought; and I have purchased Peonies every year for the past five years."

From Buffulo, N. Y._- "I am exceedingly well pleased with the Peonies. They look strong and healthy and are very much larger than I expected to get in one-year stock. Mr. - (head gardener) was equally pleased and said it was the finest lot of one-year roots he had ever seen; indeed he thought it hardly possible that some of the roots were not of two years' growth."

From Providence, R. I.- "The Peonies arrived yesterday in good condition. Their appearance gives me confidence that they will grow and thrive. I have ordered in the past from well known scedmen and the little measley stock that I received cannot be compared with your stock."

From St. Paul, Minn. - "Referring to the shipment of Peony plants from you, I beg to advise that they were absolutely the very best ever seen for the money.",

From st. Paul, Minn.- "I received your little green book and it is a dandy. I like the way you make it up, what rou say and how you say it, and the absence in it of sentimental gush - Please send me three more copies to hand to several of my friends."

From Batavia, N. Y.-"I bought a large number of Peonies from you last fall and I wish to tell you how superb they are. Very many of the new plants have blossomed and it is difficult to say which is the most beautiful. I have bought Peonies from other growers, but yours are the choicest I have."

From Collinsville, Alabama - "The Peonies came yesterday. They are very fine indeed. Most of them look like two-ycar roots that other dealers send out. I fully appreciate the quality of your stock and wish you a much-deserved success."

From Glens Falls, N. Y.--“'The Peonies have just been planted. I am as much pleased with then as I was with the lot I got from you two years ago. Those made such a magnificent showing, that I then and there foreswore my allegiance to the Rose, and I have put this lot of Peonies in the space I had previously allotted their rivals." 
PLEASE USE THIS ORDER SHEET IT WILL FACILITATE THE CORRECT HANDLING OF YOUR ORDER

To Mohican Peony Gardens

SINKING SPRING, PA.

Date

1916

Enclosed find \$

(Money Order) for which you will please forward by $\left(\begin{array}{c}\text { State whether by' } \\ \text { Express or Freigh }\end{array}\right)$ at the proper planting season, the appended

list of Peonies.

DO NOT WRITE IN THIS SPACE

Ship to (Name)

Street and No.

City or Town (Post Office)

Express or

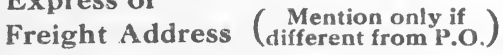

State

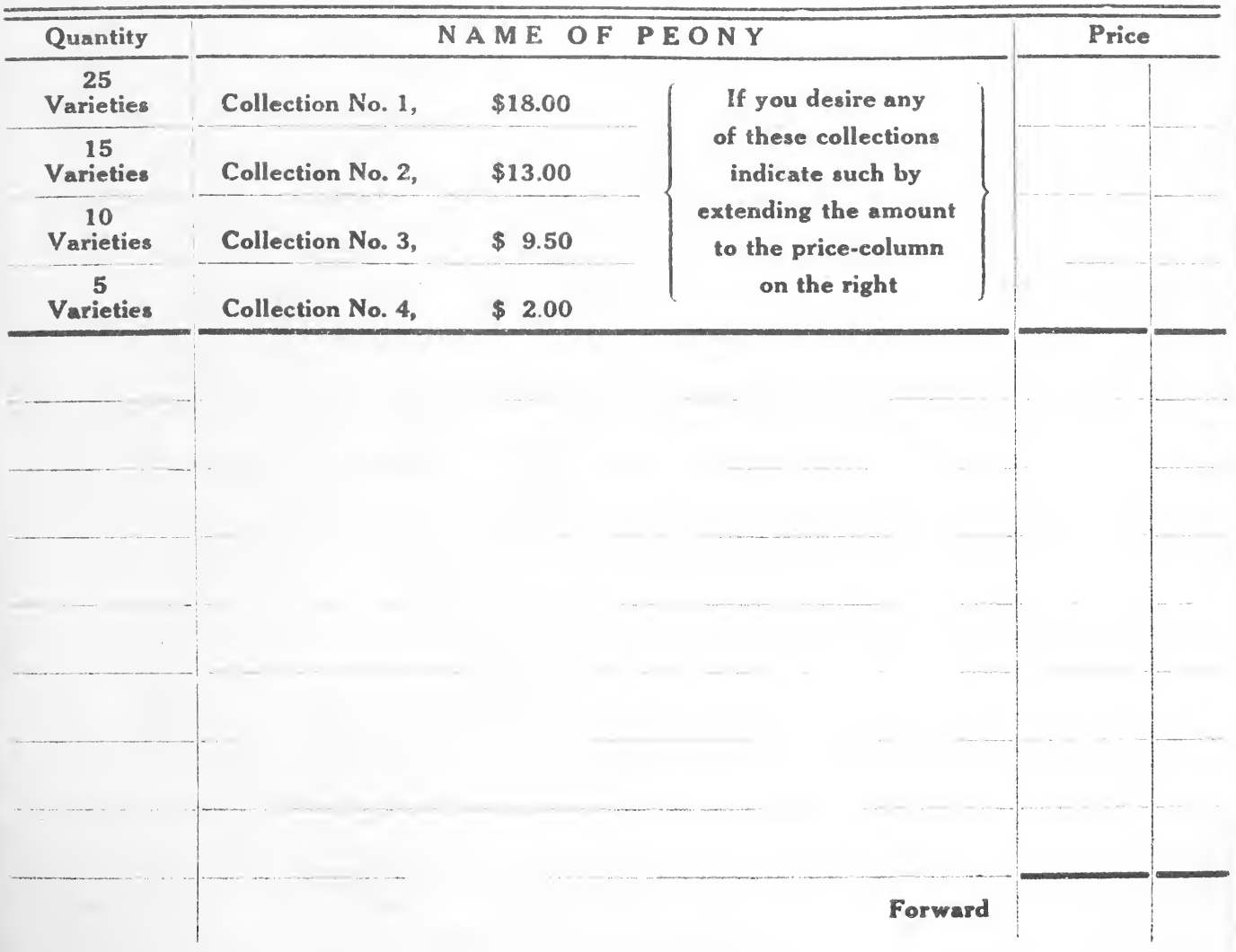


[870]

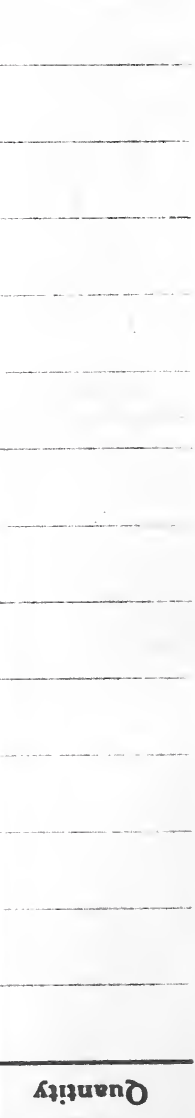




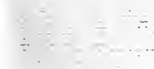


$=$ 